\title{
INFLUENCE OF LOGGING, FIRE, AND FOREST TYPE ON BIODIVERSITY AND PRODUCTIVITY IN SOUTHERN BOREAL FORESTS
}

\author{
Peter B. Reich, ${ }^{1}$ Peter Bakken, Daren Carlson, Lee E. Frelich, Steve K. Friedman, And \\ DAVID F. GRIGAL \\ Department of Forest Resources, University of Minnesota, St. Paul, Minnesota 55108 USA
}

\begin{abstract}
The effects of logging on ecosystem sustainability are controversial. Surprisingly, existing data are inadequate to allow a comprehensive evaluation of logging effects on biodiversity, composition, and productivity since appropriate comparisons of stands of similar ages and differing disturbance histories are rare. We addressed this issue using a study of 2000 plots in 80 southern boreal forest stands in northern Minnesota, USA, wherein we contrasted naturally regenerated aspen (Populus tremuloides), jack pine (Pinus banksiana), and black spruce (Picea mariana) stands established following logging or the dominant natural disturbance, wildfire, for stands of two age classes (25-40 and 70-100 yr old). For young stands, those established postlogging had higher vascular plant diversity than those postwildfire. Otherwise, we found no evidence of differing species diversity (including canopy tree, shrub, herbaceous, and bryophyte species), composition, productivity, or nitrogen cycling, in forest stands of comparable age and forest type that originated after logging compared to after wildfire. These variables, however, differed significantly among forest types, with aboveground net primary productivity and plant species diversity generally higher in aspen than jack pine stands, even when growing on comparable soils, and lowest in black spruce. Although there is evidence that logging has increased the proportional landscape dominance by aspen, a forest type with higher diversity, nutrient cycling, and productivity than other types, our evidence refutes the idea that disturbance by logging has diminished stand-scale productivity or plant diversity in comparison to the common natural disturbance, wildfire.
\end{abstract}

Key words: aspen; boreal forest; jack pine; logging; nitrogen cycling; species richness; spruce; wildfire.

\section{INTRODUCTION}

Commercial logging affects forest composition, structure, and function in numerous ways while providing a renewable resource vital to many regional economies. Concerns about effects of logging on biodiversity and sustainability have strongly influenced forest management decisions, policy debates, and the development of silvicultural systems (Salwasser 1990, Hansen et al. 1991, Gilliam and Roberts 1995, Kimmins 1996, Bergeron and Harvey 1997, Grigal and Bates 1997). It is important to better understand the impacts of logging on composition, diversity, and productivity of southern boreal forests. One-third of the world's forests are boreal and these provide important ecological services as well as $20-50 \%$ of the world's pulp, newsprint, sawn wood, and paper and paper board (Kuusela 1992a, Alexeyev and Tchmyr 1997). Warmer (largely southern) boreal forests-in essence including continental and maritime but omitting the high continental subzone (Kuusela 1992a) -represent about twothirds of the boreal land area and are responsible for

Manuscript received 16 December 1999; revised 17 July 2000; accepted 1 September 2000; final version received 2 November 2000.

${ }^{1}$ E-mail: preich@forestry.umn.edu an even greater proportion of wood removals (Kuusela 1992a, Alexeyev and Tchmyr 1997).

Logging can directly influence plant diversity and composition or sustainability of forest production through soil or forest floor disturbance (e.g., erosion, compaction, root damage), death of propagule sources (seeds, seedlings, rootstocks), altered habitat structure, removal of nutrients, or altered microclimate (Schoonmaker and McKee 1988, Duffy and Meier 1992, Bates et al. 1993, Carleton and MacLellan 1994, Gilliam and Roberts 1995, Halpern and Spies 1995, Meier et al. 1995, Kimmins 1996, Bergeron and Harvey 1997, Grigal and Bates 1997). Any of these changes can increase or decrease the suitability of a site for the persistence of, or regeneration or colonization by, specific plant species. Physical and chemical effects of logging on soils (nutrient loss, compaction, erosion) can also reduce their fertility and potential productivity. Natural tree-killing disturbances such as crown fire or windthrow may also affect plant composition and resource availability by their physical and chemical impacts on the ecosystem. Moreover, altered forest stand age structure following logging or natural disturbance will further influence composition, diversity, or productivity, as these characteristically change during stand development (Schoonmaker and McKee 1988, Duffy and Meier 1992, Bates et al. 1993, De Grandprè et al. 1993, 
Carleton and MacLellan 1994, Gilliam and Roberts 1995, Halpern and Spies 1995, Meier et al. 1995, Kimmins 1996, Bergeron and Harvey 1997, Grigal and Bates 1997). A key question is whether logging has different effects (especially those that are considered adverse from conservation perspectives) than natural disturbance, due to greater severity of disturbance, alteration of the forest age structure, or a combination of the two.

Diversity in older forests is often presumed to be high, and therefore is frequently used as a standard of comparison in judging the impacts of logging (Schoonmaker and McKee 1988, Brumelis and Carleton 1989, Hansen et al. 1991, Duffy and Meier 1992, Gilliam and Roberts 1995, Halpern and Spies 1995). Comparisons of logged secondary stands (e.g., $<20 \mathrm{yr}$, or 40-90-yrold) with intact older forest often show altered biodiversity or composition after logging (Schoonmaker and McKee 1988, Brumelis and Carleton 1989, Duffy and Meier 1992, Carleton and MacClellan 1994, Halpern and Spies 1995). However, species composition shifts naturally during stand development, and comparison of younger postlogged to older postfire or postwindthrow stands confounds age and disturbance effects. Hence, a more appropriate approach (Gilliam and Roberts $1995)$ is to control for stand age while varying disturbance type, which we have done in this study.

Such a comparison is possible in northern Minnesota, USA, because the landscape contains a mosaic of southern boreal forest stands of varying composition that have naturally regenerated after logging or canopykilling wildfire, the most common natural agent of stand initiation in the boreal forest. We have used this opportunity to examine the long-term effects of logging on plant diversity and ecosystem functioning, and we specifically ask: is there a detectable legacy of past logging on this landscape? If so, does this differ among forest types? To answer, we contrasted community and ecosystem properties in numerous forest stands originating after crown fire with stands of comparable age that originated after logging, simultaneously comparing three of the main forest types of the region, aspen, jack pine, and black spruce. We addressed two main hypotheses: (1) because of the severity of physical disturbance associated with timber harvest, postlogged forests are less diverse and productive than postwildfire forests of similar age and type; and (2) diversity and productivity vary with stand age and forest type. We also evaluated potential mechanisms responsible for the observed patterns (Noble and Slatyer 1980, Rowe 1983, Meier et al. 1995, Nguyen-Xuan et al. 2000) that might involve species differences in life history traits (including reproductive strategies), severity of disturbance, and variation in resource availability.

Focusing on both stand age and disturbance type is also relevant to considerations of the natural disturbance model (NDM) paradigm of sustainable forest management (Hunter 1993, Armstrong 1999), and in particular within the boreal forest context, in relation to stand-replacing wildfire. The central idea of NDM is that application of management practices that mimic natural disturbances may maintain ecological integrity in general (a concept difficult to define), or more pragmatically, specific parameters deemed important in a given region. By emulating natural processes to the extent possible, NDM management is hypothesized to minimize the adverse effects of timber harvest on forest ecosystem processes. Our study is relevant to the element of NDM involving the frequency of disturbances sufficiently severe to create patch-to-stand scale openings such as those following crown fires or logging. In the southern boreal zone, fire suppression and exclusion have led to a lower disturbance frequency (and hence an extended stand age frequency distribution) and timber harvest a higher disturbance frequency (and a truncated stand age frequency distribution; Carleton 2000). In the NDM framework, to the extent that fire suppression and exclusion reduce the annual burn rate, timber harvesting could replace fire, leaving the total area experiencing major disturbance each year relatively unchanged. A critical but untested assumption of NDM is that substituting one disturbance (logging) for another (wildfire) results in similar ecological outcomes, even if disturbance frequency is roughly held constant. Our study does not evaluate disturbance frequency, but our explicit focus on contrasting stands of similar ages following either wildfire or logging should allow us to consider the potential outcomes if NDM was in place, i.e., if logging frequency was managed to match the theoretical frequency of wildfires (largely suppressed during the past century in Minnesota and nearby Ontario).

\section{Methods}

Sites

Our study included 80 stands in Minnesota, USA, representing three forest types, two age classes (25-40 yr, 70-100 yr), and two modes of disturbance (crown fire, logging) leading to stand turnover and reinitiation (Table 1). Northeastern Minnesota represents the extreme southwestern range of the boreal forests of North America (Weber and Stocks 1998). Our study sites have mean annual temperatures $\left(2-4^{\circ} \mathrm{C}\right)$ within the range of warmer southern boreal forests and are dominated by major North American boreal tree species (Kuusela $1992 a$ ). We selected stands of three cover types important in Minnesota and central Canada: aspen (Populus tremuloides Michx.), jack pine (Pinus banksiana Lamb.), and black spruce (Picea mariana [Mill.] BS.P.). The two stand age classes were chosen because they were the only classes for which it was possible to find sufficient numbers of stands established after both logging and fire.

Land ownership in this region is diverse and includes private (industrial and nonindustrial), county, state, and 
federal land. Sites in this study came from all four categories and were initially identified as candidates based on management and historical records. Candidate stands were field verified, and if they met the criteria, were included in the study. Forest type and age class were determined from management records, visual inspection, and coring. We took increment cores at breast height for roughly 10 trees per site to assess tree age and estimate stand age. Stand origin was determined from management and historical records and personal communication with local land managers. Field evidence also helped determine stand origin. Indicators of fire origin included evidence of large standing snags with charcoal and fallen large trees with charcoal. Evidence of logging included the presence of large cut stumps. In some cases, it was difficult to determine stand origin because some logged stands had been burned to clean up slash, or in the opposite case, stands that had been burned had a salvage cut. Stands that were unclear as to their origin were avoided.

Given historical variation in logging techniques, the older post-logged stands were likely cut during winter and horse skidded, whereas the younger postlogged stands were likely mechanically logged during a wider range of seasons. It is generally presumed that the former is less destructive than the latter (Brumelis and Carleton 1989). It is also possible, but uncertain, that a greater number of residual trees were left in the earlier than more modern logging era. Such differences (plus variation in site preparation and post-harvest treatments) can lead to different biological responses (Bates et al. 1993, Carleton and MacLellan 1994, Carleton 2000).

Our original design called for roughly equal numbers of stands in all 12 combinations of forest type, disturbance type and age class. However, we were unable to locate young black spruce stands established following crown fire, likely due to fire suppression and exclusion in the 1960s and 1970s, and thus this cell remained open. All stands were located within UTM Zone 15, bounded by Easting coordinates 509000.406 and 600329.812 and Northing coordinates 5169566.0 and 5335194.0 , and were spatially mixed by age, origin, and type classes. Approximately one-third of all stands were sampled for one year beginning in 1995, 1996, and 1997. In each year, a roughly proportional mix of forest types, stand ages, and disturbance modes was sampled. There were no differences among years in responses to type, disturbance, or age classes (data not shown) and data from all years are pooled in this report.

Although classified and selected based on the dominant canopy tree species, each stand contained a mixture of tree species (Table 1). The dominant species made up $70 \%$ of the basal area on average (a minimum of $32 \%$ ) in jack pine and aspen stands, and more than $85 \%$ on average in black spruce stands (a minimum of $46 \%$ ). Aspen and jack pine stands were found on generally similar soil textures (Table 2), while spruce stands were on organic soils (Table 3). On average, jack pine stands were found on mineral soils with similar clay fraction, slightly greater sand fraction, and slightly lower silt fraction than aspen. However, these differences were not statistically significant, and variation in average texture among stand age and mode of origin classes within a forest type were of a larger magnitude than differences between jack pine and aspen.

\section{Methods}

The stands varied in size (generally $2-5$ ha), and for each we located a $60 \times 60 \mathrm{~m}$ core study area at least $50 \mathrm{~m}$ from an opening, with 25 points in a $5 \times 5$ grid at 10 -m spacing. Herbaceous, shrub, and woody seedling vegetation surveys (presence and percent cover) were made in midsummer at all 25 points using 0.75 $\mathrm{m}$ radius circular plots. Cover was visually estimated for all species lower than 1-m in height as the vertically projected area, using a six-class system $(<1 \%, 1-5 \%$, 6-25\%, 26-50\%, 51-75\%, and 76-100\%). Stem counts were made for shrubs (all heights) within a $1 \mathrm{~m}$ radius of plot center. Stems were counted individually up to five and then placed into classes of 6-10, 11-20, 2150 , or $>50$. Tree inventories (species and dbh of all trees $>5 \mathrm{~cm} \mathrm{dbh}$ ) were made on $4.5 \mathrm{~m}$ radius plots centered at all 25 points at every stand. Using the same protocol (plot size and cover classes) as for herbaceous plants, bryophyte species were censused at all 25 plots on 55 of the 80 sites, representing approximately five replicates of each of the 11 available combinations of forest type, disturbance type, and age class. Bryophyte species were not surveyed on all sites because of the effort and expense involved. Within the $0.75 \mathrm{~m}$ radius, bryophytes were censused on all surfaces, including downed logs, bases of trees, snags, stumps, and forest floor.

At 10 of the 25 points in each stand, randomly selected (and offset $1 \mathrm{~m}$ from the vegetation survey point center), an index of soil net nitrogen mineralization was assessed using midsummer in situ field soil incubations $(0-20 \mathrm{~cm}$, mineral soil) using the semi-open tube method (Zak and Grigal 1991). In late June or early July, a PVC tube ( $5 \mathrm{~cm}$ diameter) was driven 20 $\mathrm{cm}$ deep into the soil to collect an initial mineral soil sample. A paired tube was left in the soil for an incubation period of 5-6 wk, and then collected. In the lab, stones, leaves, woody debris, and roots were removed from each sample and the soil was homogenized. Soil nitrogen was extracted from $30 \mathrm{~g}$ of fieldmoist soil in $60 \mathrm{~mL}$ of $2 \mathrm{~mol} / \mathrm{L} \mathrm{KCl}$ solution. The extract was then analyzed for $\mathrm{NH}_{4}{ }^{+}$and $\mathrm{NO}_{3}{ }^{-}$(Research Analytical Laboratory, University of Minnesota, St. Paul, Minnesota, USA) by conversion to nitrate with salicylic acid and subsequent copper cadmium reduction, followed by calorimetric analysis. Nitrogen mineralization was calculated as the difference in mineral 
TABLE 1. Site characteristics for 80 forest stands in northeastern Minnesota, USA.

\begin{tabular}{lllrrrrr}
\hline \hline Stand type & Age class & Origin & $N$ & Age $(\mathrm{yr})$ & $\begin{array}{c}\text { Total BA } \\
\left(\mathrm{m}^{2} / \mathrm{ha}\right)\end{array}$ & $\begin{array}{c}\text { Jack pine BA } \\
\left(\mathrm{m}^{2} / \mathrm{ha}\right)\end{array}$ & $\begin{array}{c}\text { Aspen BA } \\
\left(\mathrm{m}^{2} / \mathrm{ha}\right)\end{array}$ \\
\hline Aspen & old & postfire & 8 & $76.9(4.4)$ & $26.2(3.5)$ & $0.5(0.3)$ & $16.5(2.2)$ \\
Aspen & old & postlogged & 8 & $84.3(3.1)$ & $30.5(2.0)$ & $0.4(0.2)$ & $19.8(2.7)$ \\
Aspen & young & postfire & 7 & $29.6(2.8)$ & $21.9(2.4)$ & $0.5(0.5)$ & $16.9(2.0)$ \\
Aspen & young & postlogged & 8 & $33.8(1.6)$ & $18.5(2.4)$ & $1.7(1.2)$ & $13.5(2.4)$ \\
Black spruce & old & postfire & 6 & $97.5(9.0)$ & $15.9(3.8)$ & $0.1(0.1)$ & $0.0(0.0)$ \\
Black spruce & old & postlogged & 10 & $76.4(3.0)$ & $19.4(5.8)$ & $0.0(0.0)$ & $0.0(0.0)$ \\
Black spruce & young & postlogged & 3 & $32.0(6.7)$ & $6.2(5.6)$ & $1.4(1.4)$ & $0.0(0.0)$ \\
Jack pine & old & postfire & 7 & $94.1(7.7)$ & $27.4(3.3)$ & $21.1(3.9)$ & $1.2(0.6)$ \\
Jack pine & old & postlogged & 7 & $74.3(3.8)$ & $30.9(2.8)$ & $16.9(1.7)$ & $2.3(1.3)$ \\
Jack pine & young & postfire & 7 & $33.1(3.2)$ & $22.8(2.1)$ & $17.8(2.2)$ & $1.3(0.3)$ \\
Jack pine & young & postlogged & 9 & $29.3(3.0)$ & $19.8(2.4)$ & $15.9(2.1)$ & $0.6(0.2)$ \\
\hline
\end{tabular}

Notes: Data are means (with $1 \mathrm{SE}$ in parentheses) for stand age, aboveground biomass, total basal area (BA), and basal area by major species. $N=$ number of stands.

$\mathrm{N}\left(\mathrm{NH}_{4}^{+}+\mathrm{NO}_{3}^{-}\right)$between the initial and incubated soil samples.

Annual aboveground net primary production (ANPP) and litterfall nitrogen cycling of the woody plants were assessed using standard methods (e.g., Pastor et al. 1984, Grigal and Homann 1994, Reich et al. 1997). Litterfall was collected using $28 \times 34-\mathrm{cm}$ traps near ground level over a full year period at 10 randomly selected plots (9 or 15 in the first year) spatially offset from the herbaceous survey plot centerpoint, oven dried and weighed, and analyzed for $\mathrm{N}$ concentration (Kjeldahl method, Research Analytical Laboratory, University of Minnesota). Annual woody plant ANPP was assumed to be the sum of wood production and woody plant litterfall production.

Annual aboveground wood production was estimated using radial growth in the most recent $10 \mathrm{yr}$ and estimates of stemwood biomass based on dbh, as follows. A subsample of trees ( $~ 15-30$ per site, 2000 total $)$ were cored at breast height and the most recent 10 -yr radial growth was measured. At each site, one tree of the dominant species was cored in every plot where it occurred, with two cores at $90^{\circ}$ angles from each other taken from every tree (the mean of the values was calculated). Other species were sampled at a frequency (proportion of plots) equal to their proportion of stand basal area if the species accounted for at least $20 \%$ of the stand basal area. For these sets of individual trees we developed site-specific regression relationships for each species (mean $r^{2}>0.97$ ) between dbh in 1995 , 1996, or 1997 and dbh 10 yr previously, which were then applied to all live trees on the 25 plots at the time of censusing to provide estimates of $\mathrm{dbh}$ at the two time periods. In cases when there were insufficient increment cores taken to establish plot-specific regressions for a given species (i.e., for species relatively unimportant in that stand), we estimated prior dbh using the overall regression relationship across all trees and sites for that species. Regional species biomass equations for stemwood (Ter-Mikaelian and Korzukhin 1997) were then applied to all inventoried trees using current and past dbh to estimate current and past stemwood biomass, and scaled to the hectare from the censused area. The difference in total biomass between the two periods, divided by 10 , provided an estimate of the annual stemwood production. We did not include wood production of trees that died during the decade in question because it was likely negligible and difficult to estimate accurately. Although littertraps capture most fine litterfall from tall shrubs, they do not capture litterfall from short herbaceous vegetation and short shrubs. We also did not measure wood production of shrubs. Thus, our values for ANPP slightly underestimate total vascular plant ANPP.

TABLE 2. Mineral soils data for 61 aspen and jack pine forest stands in northeastern Minnesota, USA.

\begin{tabular}{llllllllc}
\hline \hline Stand type & Age class & Origin & Sand $(\%)$ & Clay $(\%)$ & Silt $(\%)$ & Soil pH & C $(\%)$ & $\begin{array}{c}\text { CEC } \\
\left(\mathrm{mmol}_{\mathrm{c}} / 100 \mathrm{~g}\right)\end{array}$ \\
\hline Aspen & old & postfire & $70.3(2.9)$ & $5.2(1.4)$ & $24.5(1.8)$ & $6.5(0.2)$ & $2.0(0.3)$ & $18.4(2.6)$ \\
Aspen & old & postlogged & $77.8(2.1)$ & $3.4(0.5)$ & $18.8(2.2)$ & $6.3(0.2)$ & $1.5(0.2)$ & $17.3(1.6)$ \\
Aspen & young & postfire & $75.3(2.1)$ & $4.0(0.7)$ & $20.7(1.9)$ & $5.8(0.1)$ & $2.2(0.6)$ & $19.6(3.3)$ \\
Aspen & young & postlogged & $73.5(2.3)$ & $5.7(0.8)$ & $20.8(2.1)$ & $6.2(0.2)$ & $1.3(0.2)$ & $12.9(1.4)$ \\
Jack pine & old & postfire & $80.1(3.8)$ & $5.6(1.3)$ & $14.3(2.7)$ & $6.2(0.2)$ & $1.3(0.5)$ & $15.1(3.6)$ \\
Jack pine & old & postlogged & $82.4(3.7)$ & $3.3(0.8)$ & $14.3(3.1)$ & $6.2(0.1)$ & $1.6(0.4)$ & $14.6(2.3)$ \\
Jack pine & young & postfire & $74.1(3.4)$ & $6.2(1.1)$ & $19.6(2.7)$ & $6.4(0.2)$ & $1.7(0.2)$ & $17.6(4.2)$ \\
Jack pine & young & postlogged & $78.1(3.0)$ & $4.4(1.0)$ & $17.5(2.2)$ & $6.1(0.2)$ & $2.4(0.7)$ & $20.8(3.3)$ \\
\hline
\end{tabular}

Note: Data are means (with $1 \mathrm{SE}$ in parentheses) for soil textural classes, soil pH (water), cation exchange capacity (CEC), percentage base saturation, and extractable cations. 
TABle 1. Extended.

\begin{tabular}{ccc}
\hline \hline $\begin{array}{c}\text { Black spruce BA } \\
\left(\mathrm{m}^{2} / \mathrm{ha}\right)\end{array}$ & $\begin{array}{c}\text { Balsam fir BA } \\
\left(\mathrm{m}^{2} / \mathrm{ha}\right)\end{array}$ & $\begin{array}{c}\text { Biomass } \\
(\mathrm{Mg} / \mathrm{ha})\end{array}$ \\
\hline $0.5(0.4)$ & $4.1(1.0)$ & $96.8(14.7)$ \\
$0.1(0.1)$ & $4.0(1.1)$ & $117.0(7.5)$ \\
$0.3(0.2)$ & $0.8(0.6)$ & $52.3(7.3)$ \\
$0.3(0.3)$ & $0.7(0.3)$ & $50.9(6.8)$ \\
$14.2(3.9)$ & $0.0(0.0)$ & $42.1(9.6)$ \\
$18.2(5.3)$ & $0.1(0.1)$ & $49.6(13.2)$ \\
$4.6(4.2)$ & $0.0(0.0)$ & $22.3(16.0)$ \\
$1.0(0.8)$ & $1.3(0.7)$ & $76.6(13.6)$ \\
$1.8(1.6)$ & $1.0(0.5)$ & $76.8(13.1)$ \\
$1.5(0.8)$ & $0.0(0.0)$ & $43.2(9.0)$ \\
$1.4(0.7)$ & $0.6(0.2)$ & $33.2(7.5)$ \\
\hline
\end{tabular}

To assess soil texture and nutrient status, five soil pits per site were dug with a soil spade, mineral soil samples collected from the $0-30 \mathrm{~cm}$ depth, and samples were composited by site and homogenized in the laboratory. Near each soil pit, four forest floor samples were collected using a $10 \mathrm{~cm}$ diameter steel ring. The ring was punched into the forest floor in four spots, the depth of the forest floor was recorded, and all forest floor material within the ring was collected and composited. The forest floor included leaves, duff, sticks, and roots, and excluded above ground live plants. Soil texture was measured for all mineral soils (i.e., all aspen and jack pine stands) using the hydrometer method. All mineral soil samples were analyzed for percentage of base saturation and cation exchange capacity using the summation of exchangeable $\mathrm{K}, \mathrm{Ca}, \mathrm{Mg}, \mathrm{Na}$, and $\mathrm{H}^{+}$(Research Analytical Laboratory, University of Minnesota). Base cations were extracted by leaching $3 \mathrm{~g}$ air dried soil with successive aliquots of $1 \mathrm{~mol} / \mathrm{L} \mathrm{NH}_{4} \mathrm{OAc}(\mathrm{pH} 7)$ to total $60 \mathrm{~mL}$, and their concentrations in the leachate were determined by inductively coupled plasma-atomic emission spectrometry (ICP-AES). All organic (black spruce) soil samples and all forest floor samples were analyzed for total $\mathrm{P}, \mathrm{K}, \mathrm{Ca}, \mathrm{Mg}, \mathrm{Mn}, \mathrm{Al}, \mathrm{Fe}, \mathrm{Na}, \mathrm{Zn}, \mathrm{Cu}, \mathrm{B}, \mathrm{Pb}$, $\mathrm{Ni}, \mathrm{Cr}$, and $\mathrm{Cd}$ using ICP-AES (Research Analytical Laboratory, University of Minnesota). Soil \%C was determined by dry combustion at $2500^{\circ} \mathrm{F}\left(1371^{\circ} \mathrm{C}\right)$ and subsequent measurement of $\mathrm{CO}_{2}$ evolution by IR spec-

TABle 2. Extended.

\begin{tabular}{cccc}
\hline \hline $\begin{array}{c}\text { Base saturation } \\
(\%)\end{array}$ & $\begin{array}{c}\mathrm{K} \\
\left(\mathrm{mmol}_{\mathrm{c}} / 100 \mathrm{~g}\right)\end{array}$ & $\begin{array}{c}\mathrm{Ca} \\
\left(\mathrm{mmol}_{\mathrm{c}} / 100 \mathrm{~g}\right)\end{array}$ & $\begin{array}{c}\mathrm{Mg} \\
\left(\mathrm{mmol}_{\mathrm{c}} / 100 \mathrm{~g}\right)\end{array}$ \\
\hline $16.1(0.8)$ & $0.12(0.02)$ & $2.21(0.31)$ & $0.58(0.11)$ \\
$22.4(4.6)$ & $0.19(0.05)$ & $2.78(0.57)$ & $0.88(0.27)$ \\
$15.1(3.8)$ & $0.13(0.03)$ & $2.11(0.56)$ & $0.57(0.15)$ \\
$24.6(2.9)$ & $0.12(0.01)$ & $2.45(0.44)$ & $0.68(0.15)$ \\
$22.8(2.2)$ & $0.13(0.02)$ & $2.63(0.71)$ & $1.07(0.50)$ \\
$16.5(2.3)$ & $0.13(0.02)$ & $1.69(0.30)$ & $0.39(0.07)$ \\
$19.4(3.3)$ & $0.10(0.03)$ & $2.32(0.46)$ & $0.80(0.26)$ \\
$16.9(1.8)$ & $0.13(0.02)$ & $2.37(0.31)$ & $0.75(0.18)$ \\
\hline
\end{tabular}

trum absorption using a LECO CR-12 carbon furnace (St. Joseph, Michigan, USA).

\section{Analyses}

Both analysis of variance and maximum likelihood log-linear analysis (Sokal and Rohlf 1981) were used to test for differences among disturbance type (fire vs. logging), stand age, and forest type in several diversity measures. Log-linear analysis and ANOVA (Sokal and Rohlf 1981) differ in several ways. In log-linear analysis, the response variable is assumed to have a poisson distribution and a maximum likelihood method is used, whereas ANOVA assumes a normal distribution and uses the least squares method. Analyses of species richness and diversity indices gave similar results regardless of the approach. However, site values for richness of all plants, bryophytes, vascular plants, herbaceous plants, and woody plants were normally distributed $(P$ $>0.05$, Shapiro Wilk $W$ test for normality), hence results from ANOVA are shown herein. The stand or site $(n=80)$ was generally considered the experimental unit. Composition and richness were summed among plots to provide stand-scale measures and the mean was calculated among plots to give plot-scale measures. Given the unbalanced design due to the lack of young postfire spruce stands, ANOVA for forest type, stand age, and disturbance effects and interactions were conducted for jack pine and aspen stands (without spruce stands). Then, analyses were made for forest type, disturbance, and their interaction using all three forest types but only in old stands; and finally for forest type, stand age, and their interaction using all three forest types but only postlogged stands.

Analyses were made of evenness and Shannon's diversity index per stand and per plot (PC-Ord 4.0, MjM Software Design, Gleneden Beach, Oregon, USA), and of Whittaker's $\beta$-diversity index. Estimates of multiplestand species richness were made by randomly drawing equal numbers of stands from selected stand contrasts within the data set, counting the total number of species in all such stands, and repeating the process several times.

Species lists for every combination of disturbance, age, and forest type were used to assess whether species were rare or abundant. Indicator species analysis (Dufrêne and Legendre 1997) was used to test whether species were significantly associated with (i.e., "indicated") either postfire or postlogging stands. Nonmetric multidimensional scaling (PC-Ord 4.0) was used to ordinate the community composition among stands and plots, because it assumes only a monotonic (not a linear) relationship between ordination distance and compositional dissimilarity. Ordination of the vascular plants at ground layer and the bryophytes species communities were conducted at a plot scale based on abundance (percent cover) and on a stand scale based on the percent frequency of occurrence among the 25 plots on each site for each individual species. Since the re- 
TABLE 3. Forest floor and organic soils data for 80 forest stands in northeastern Minnesota, USA.

\begin{tabular}{lllllllll}
\hline \hline Stand type & Age class & Origin & Sampled strata & $\mathrm{P}(\mu \mathrm{g} / \mathrm{g})$ & $\mathrm{K}(\mu \mathrm{g} / \mathrm{g})$ & $\mathrm{Ca}(\mu \mathrm{g} / \mathrm{g})$ & $\mathrm{Mg}(\mu \mathrm{g} / \mathrm{g})$ & $\mathrm{pH}$ \\
\hline Aspen & old & postfire & forest floor & $987(78)$ & $1382(159)$ & $11181(1370)$ & $3376(737)$ & $\ldots$ \\
Aspen & old & postlogged & forest floor & $885(87)$ & $1154(156)$ & $9885(1622)$ & $3513(544)$ & $\ldots$ \\
Aspen & young & postfire & forest floor & $768(83)$ & $1032(109)$ & $6350(1524)$ & $1405(177)$ & $\ldots$ \\
Aspen & young & postlogged & forest floor & $833(150)$ & $1942(797)$ & $7445(1471)$ & $2479(501)$ & $\ldots$ \\
Jack pine & old & postfire & forest floor & $692(97)$ & $987(106)$ & $5542(1309)$ & $2733(885)$ & $\ldots$ \\
Jack pine & old & postlogged & forest floor & $729(104)$ & $1119(127)$ & $8019(2537)$ & $2023(370)$ & $\ldots$ \\
Jack pine & young & postfire & forest floor & $819(66)$ & $1122(60)$ & $7505(634)$ & $1724(198)$ & $\ldots$ \\
Jack pine & young & postlogged & forest floor & $674(46)$ & $989(72)$ & $6586(382)$ & $2145(313)$ & $\ldots$ \\
Black spruce & old & postfire & forest floor & $676(45)$ & $784(106)$ & $5593(2068)$ & $1177(162)$ & $\ldots$ \\
Black spruce & old & postlogged & forest floor & $671(46)$ & $892(87)$ & $4922(800)$ & $1358(231)$ & $\ldots$ \\
Black spruce & young & postlogged & forest floor & $842(86)$ & $891(198)$ & $4656(713)$ & $1389(427)$ & $\ldots$ \\
Black spruce & old & postfire & soil & $560(30)$ & $186(19)$ & $7142(2285)$ & $852(184)$ & $5.3(0.2)$ \\
Black spruce & old & postlogged & soil & $585(38)$ & $260(46)$ & $5170(538)$ & $1076(175)$ & $5.4(0.1)$ \\
Black spruce & young & postlogged & soil & $718(2)$ & $180(3)$ & $7643(2088)$ & $1118(204)$ & $5.4(0.2)$ \\
\hline
\end{tabular}

Notes: Data are mean total $\mathrm{P}, \mathrm{K}, \mathrm{Ca}, \mathrm{Mg}$, and $\mathrm{pH}$. Ellipses indicate no data. Standard errors are reported in parentheses.

sults were similar either way, only the latter are shown. A Monte Carlo test was used to detect if the ordination was extracting stronger axes than would be expected by chance $(P<0.05)$.

Multi-response permutation procedures (MRPP) were used to test for differences in similarity of overall plant composition (stand-scale) among forest types, stand age, and disturbance classes (PC-Ord 4.0, MjM Software Design, Gleneden Beach, Oregon). Vascular plant composition (including woody and herbaceous species) from the $0.75 \mathrm{~m}$ radius ground flora census plots were used in these analyses. Sorenson's (BrayCurtis) index was used as the distance measure among stands.

\section{RESULTS}

For any forest type, there was no evidence that stands of either age class had lower species richness or diversity, or lower levels of productivity, soil fertility, or nutrient cycling if originated after logging rather than wildfire. These findings were consistent for several

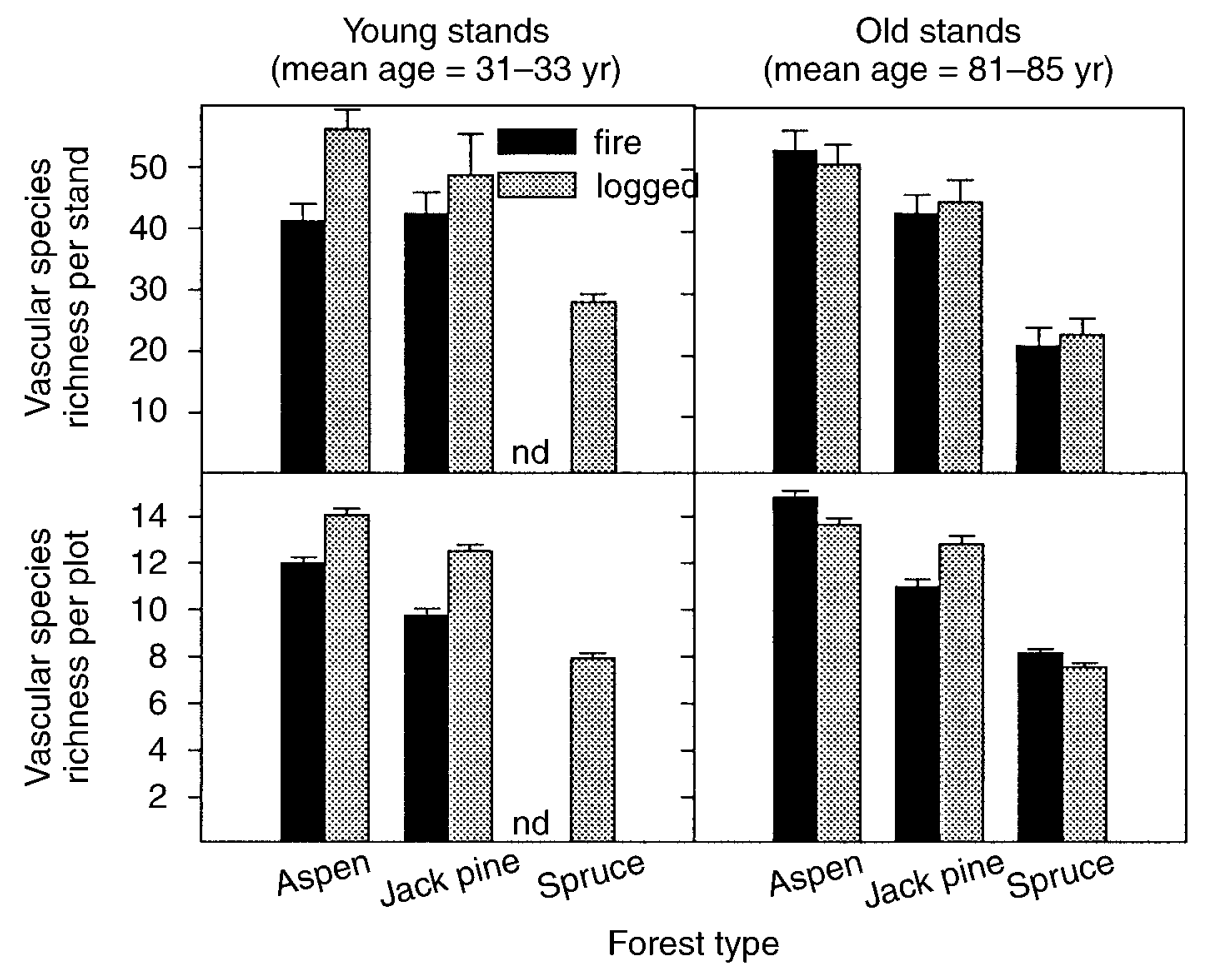

FIG. 1. Effects of disturbance type (fire vs. logging), stand age, and forest type on the number (mean $+1 \mathrm{SE}$ ) of vascular plant species per plot (mean of $251.8-\mathrm{m}^{2}$ plots) and per stand (aggregate of 25 plots). The "nd" indicates that no data are available for young postfire spruce stands, likely due to fire suppression. All 80 stands were used in this analysis. 


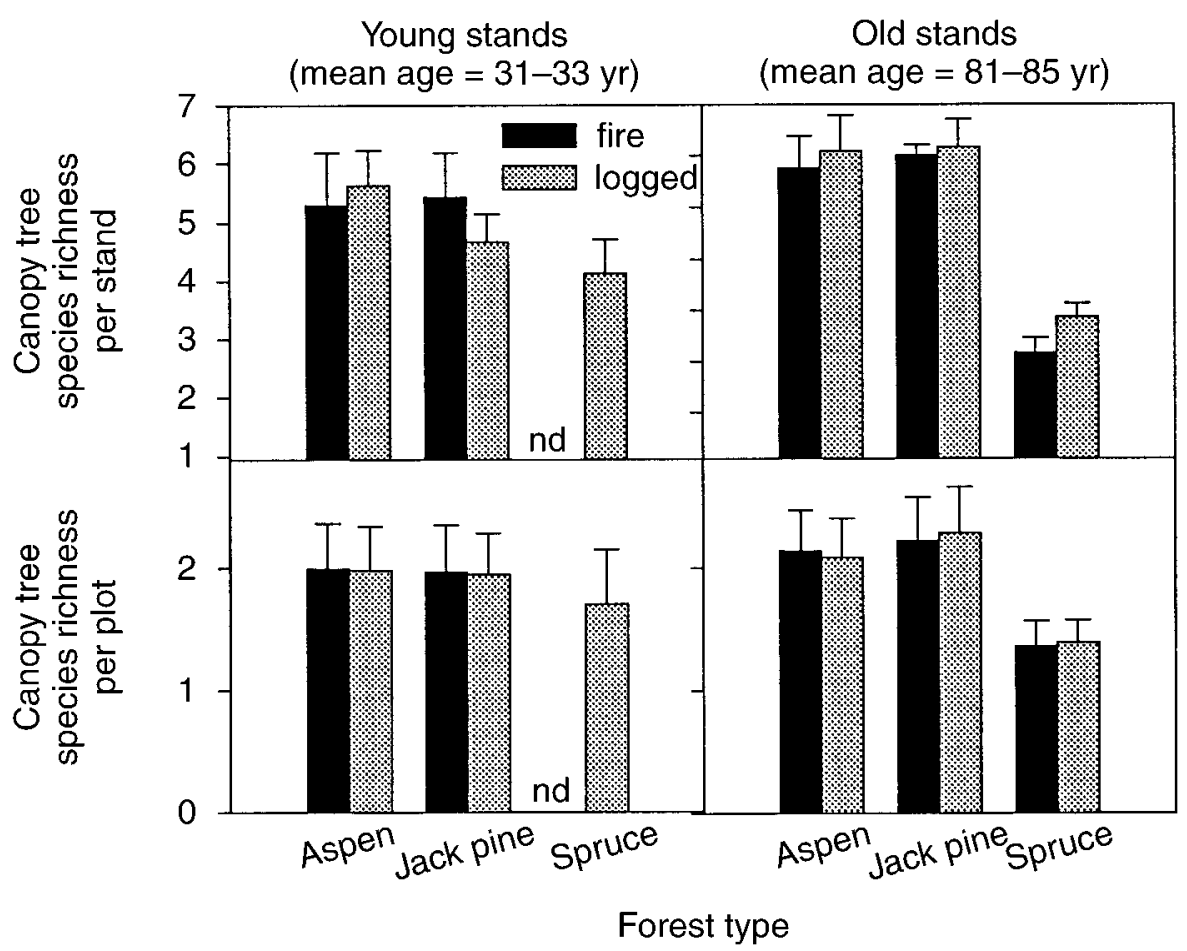

FIG. 2. Effects of disturbance type (fire vs. logging), stand age, and forest type on the number (mean $+1 \mathrm{SE}$ ) of canopy tree species per plot (mean of $25,64-\mathrm{m}^{2}$ plots) and per stand (aggregate of 25 plots). The "nd" indicates that no data are available (see Fig. 1). All 80 stands were used in this analysis.

measures of plant diversity, total species richness, or species richness within functional groups.

\section{Vascular plant species richness}

Comparisons among forest types, controlling for comparable disturbance history and stand age classes, consistently showed significantly greater vascular plant species richness in aspen than jack pine stands, with much lower richness in black spruce stands (Figs. 12 , Table 4). This was generally true at both stand and plot scales. In analyses of logged stands of all three forest types, young stands had significantly greater herbaceous (and total vascular) plant species richness than old stands at the stand scale, but significantly lower canopy tree species richness at a plot scale (Table 4, Figs. 1-2). In analyses of old stands of all three forest types, there were no significant differences in any measure of species richness between postlogging and postfire stands (Table 4, Figs. 1-2).

Analyses that included both origin and stand age had to be restricted to the aspen and jack pine types because of the lack of young postfire spruce stands. In both aspen and jack pine stands, mean herbaceous and vascular plant species richness (of the ground flora) per plot and per stand were significantly greater in postlogged than postfire stands for the young age class and similar for both disturbance types in the old stands (Fig. 1, Table 4). Canopy tree species richness per plot and per stand (Fig. 2) were not significantly different (Table
4) for postlogged vs. postfire aspen and jack pine stands in either age class, but was greater in old than young stands at the plot scale.

\section{Bryophyte and total richness}

Bryophyte species richness did not differ significantly postfire vs. postlogging, nor in relation to stand age or forest type (Table 4; Fig. 3). The mean number of bryophytes species per stand was higher overall in aspen (32) than in black spruce (28) or jack pine (28), and was higher in postfire than postlogged young aspen stands, but none of these differences were significant (Table 4). Despite similar richness, bryophyte cover was much greater (threefold) in spruce than in either jack pine or aspen stands (data not shown). Total plant species richness (vascular plants plus bryophytes) was not consistently different between either disturbance (fire vs. logging) or age classes (Table 4, Fig. 4), but was lower in spruce than the other forest types and showed a significant interaction at the stand scale between forest type and age for jack pine vs. aspen (Table 4).

\section{Diversity indices}

Several measures of species diversity revealed generally similar patterns in terms of comparisons among forest types, disturbance types, and age classes (Table $5)$, as did analyses of species richness. For vascular plants, both Shannon's diversity index and Whittaker's 
TABLE 4. Analyses of variance summary for biodiversity data.

\begin{tabular}{|c|c|c|c|c|c|c|c|c|c|}
\hline \multirow[b]{2}{*}{ Parameter } & \multicolumn{4}{|c|}{ Effects of forest type and disturbance } & \multicolumn{4}{|c|}{ Effects of forest type and stand age } & \multirow[b]{2}{*}{$R^{2}$} \\
\hline & $R^{2}$ & $\begin{array}{c}\text { Forest } \\
\text { type }\end{array}$ & Origin & $\begin{array}{c}\text { Forest } \\
\text { type } \\
\times \text { origin }\end{array}$ & $R^{2}$ & $\begin{array}{c}\text { Forest } \\
\text { type }\end{array}$ & Stand age & $\begin{array}{c}\text { Forest } \\
\text { type } \\
\times \text { age }\end{array}$ & \\
\hline Total species/stand & 0.47 & 0.0003 & 0.81 & 0.79 & 0.42 & 0.008 & 0.54 & 0.28 & 0.23 \\
\hline Total species/plot & 0.47 & 0.0003 & 0.58 & 0.96 & 0.38 & 0.009 & 0.35 & 0.55 & 0.26 \\
\hline Vascular species/stand & 0.65 & 0.0001 & 0.99 & 0.78 & 0.66 & 0.0001 & 0.06 & 0.95 & 0.28 \\
\hline Vascular species/plot & 0.63 & 0.0001 & 0.83 & 0.18 & 0.55 & 0.0001 & 0.92 & 0.87 & 0.24 \\
\hline Herbaceous species/stand & 0.65 & 0.0001 & 0.79 & 0.48 & 0.69 & 0.0001 & 0.03 & 0.90 & 0.32 \\
\hline Herbaceous species/plot & 0.69 & 0.0001 & 0.93 & 0.07 & 0.59 & 0.0001 & 0.65 & 0.62 & 0.27 \\
\hline Shrub species/stand & 0.41 & 0.0001 & 0.98 & 0.97 & 0.43 & 0.0002 & 0.43 & 0.92 & 0.15 \\
\hline Shrub species/plot & 0.04 & 0.69 & 0.86 & 0.76 & 0.07 & 0.41 & 0.80 & 0.97 & 0.07 \\
\hline Tree species/stand & 0.44 & 0.0001 & 0.35 & 0.34 & 0.30 & 0.05 & 0.46 & 0.20 & 0.07 \\
\hline Tree species/plot & 0.37 & 0.0002 & 0.21 & 0.82 & 0.40 & 0.008 & 0.01 & 0.15 & 0.34 \\
\hline Bryophyte species/stand & 0.12 & 0.23 & 0.60 & 0.89 & 0.10 & 0.99 & 0.91 & 0.30 & 0.18 \\
\hline Bryophyte species/plot & 0.09 & 0.42 & 0.67 & 0.79 & 0.11 & 0.77 & 0.41 & 0.48 & 0.12 \\
\hline Shannon's index/stand & 0.73 & 0.0001 & 0.86 & 0.69 & 0.73 & 0.0001 & 0.11 & 0.99 & 0.28 \\
\hline Evenness & 0.07 & 0.30 & 0.94 & 0.68 & 0.16 & 0.06 & 0.99 & 0.34 & 0.13 \\
\hline Whittaker's $\beta$ diversity & 0.20 & 0.02 & 0.56 & 0.46 & 0.11 & 0.36 & 0.34 & 0.99 & 0.21 \\
\hline
\end{tabular}

Notes: ANOVA results are shown for species richness of all censused plants (total vascular plus bryophyte), of all vascular plants, of herbaceous, shrub, tree, and moss species at both stand and plot scales (aggregate and mean number of species in 25 plots per stand, respectively), in relation to: (left) forest type and disturbance (mode of stand origin), for old stands of three types (aspen, jack pine, and black spruce) in two disturbance classes (postlogging and postfire); (center) forest type and stand age, for logged stands of all three types in two age classes (young and old); (right) forest type, stand age (young vs. old), and disturbance (mode of stand origin), for stands or two types (aspen and jack pine). $R^{2}$ values shown are for the whole model. $P$ values are shown for main effects and interactions (boldface type indicates $P<0.10$ ).

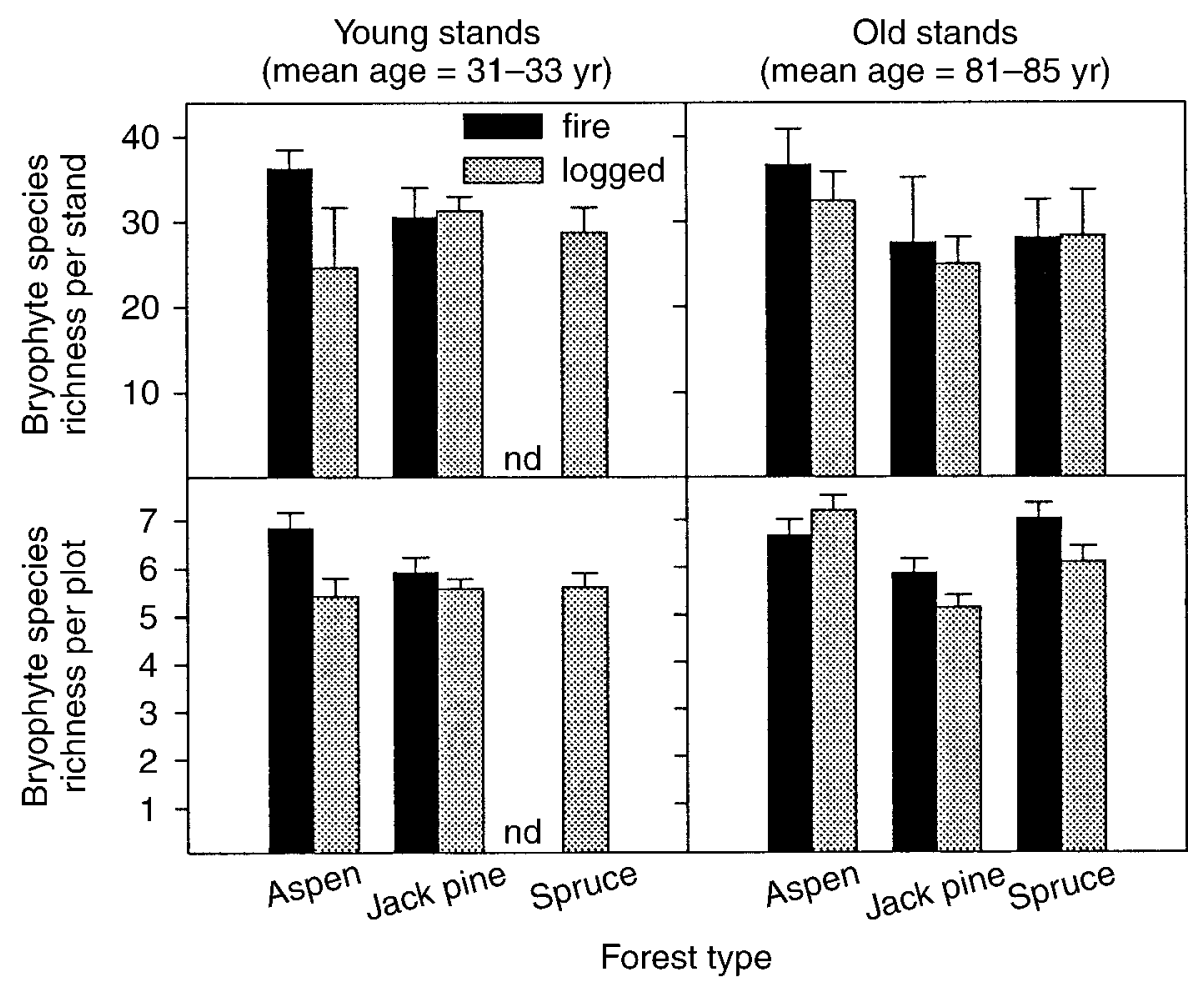

FIG. 3. Effects of disturbance type (fire vs. logging), stand age, and forest type on the number (mean +1 SE) of bryophytes species per plot (mean of $251.8-\mathrm{m}^{2}$ plots) and per stand (aggregate of 25 plots). The 55 stands surveyed for bryophyte composition were used in this analysis. The "nd" indicates that no data are available (see Fig. 1). 
TABLE 4. Extended.

\begin{tabular}{cccl}
\hline \hline \multicolumn{3}{c}{ Effects of forest type, stand age, and disturbance } \\
\hline $\begin{array}{c}\text { Forest } \\
\text { type }\end{array}$ & Age & Origin & \multicolumn{1}{c}{ Interaction } \\
\hline $\mathbf{0 . 0 6}$ & 0.79 & 0.98 & Forest type $\times$ age $(\boldsymbol{P}=\mathbf{0 . 0 4})$ \\
$\mathbf{0 . 0 2}$ & $\mathbf{0 . 0 7}$ & 0.89 & none \\
$\mathbf{0 . 0 2}$ & 0.74 & $\mathbf{0 . 0 4}$ & Age $\times$ origin $(\boldsymbol{P}=\mathbf{0 . 0 2})$ \\
$\mathbf{0 . 0 1}$ & 0.22 & $\mathbf{0 . 0 6}$ & none \\
$\mathbf{0 . 0 0 6}$ & 0.73 & $\mathbf{0 . 0 3}$ & Age $\times$ origin $(\boldsymbol{P}=\mathbf{0 . 0 0 6})$ \\
$\mathbf{0 . 0 0 2}$ & 0.43 & $\mathbf{0 . 0 8}$ & none \\
0.50 & 0.96 & 0.38 & none \\
0.26 & 0.96 & 0.55 & none \\
0.77 & 0.12 & 0.96 & none \\
$\mathbf{0 . 0 7}$ & $\mathbf{0 . 0 0 1}$ & 0.14 & Forest type $\times$ age $(\boldsymbol{P}=\mathbf{0 . 0 8})$ \\
0.23 & 0.94 & 0.19 & none \\
0.26 & 0.61 & 0.40 & none \\
$\mathbf{0 . 0 2}$ & 0.83 & $\mathbf{0 . 0 2}$ & Age $\times$ origin $(\boldsymbol{P}=\mathbf{0 . 0 1})$ \\
0.23 & 0.85 & 0.16 & none \\
$\mathbf{0 . 0 3}$ & 0.15 & 0.95 & Forest type $\times$ origin $(\boldsymbol{P}=\mathbf{0 . 0 3})$ \\
\hline & & &
\end{tabular}

ß-diversity index (calculated among plots within a stand) were significantly lower in spruce than either jack pine or aspen stands (Tables 4 and 5). Evenness was similar among forest types, origin, and age classes. Analyses for Shannon's diversity index of aspen and jack pine stands that included all origin and stand age classes showed forest type and origin effects, plus an age class $\times$ origin interaction (Table 4 ). Shannon's index was significantly higher postlogging than postfire for young stands of both types, but there was no difference for older stands (Tables 4 and 5). Aspen stands had higher Shannon's index than jack pine stands but a lower Whittaker's B-diversity index postfire than in jack pine (with no difference postlogging).

Shannon's diversity index was very closely related to species richness among all 80 stands $\left(r^{2}=0.98\right)$ and within each forest type $\left(r^{2}>0.9\right)$, hence results for these two measures are similar in relation to forest types, stand age classes, and disturbance regimes. Evenness and Whittaker's $B$-diversity index were not consistently closely related to species richness within forest types or among all stands pooled, so they convey additional information about other aspects of diversity beyond species richness. However, these several indices generally indicated similar patterns as species richness, which we therefore use generally throughout this paper as a synonym for diversity in general.

\section{Composition}

Stands of the same type established following logging vs. wildfire did not differ appreciably in composition or in the numbers, abundances and types of species that were rare or common. Ordination (Fig. 5) and tests of similarity indices (Table 6) detected no systematic differences in community composition between postlogged and postfire stands, but found substantial

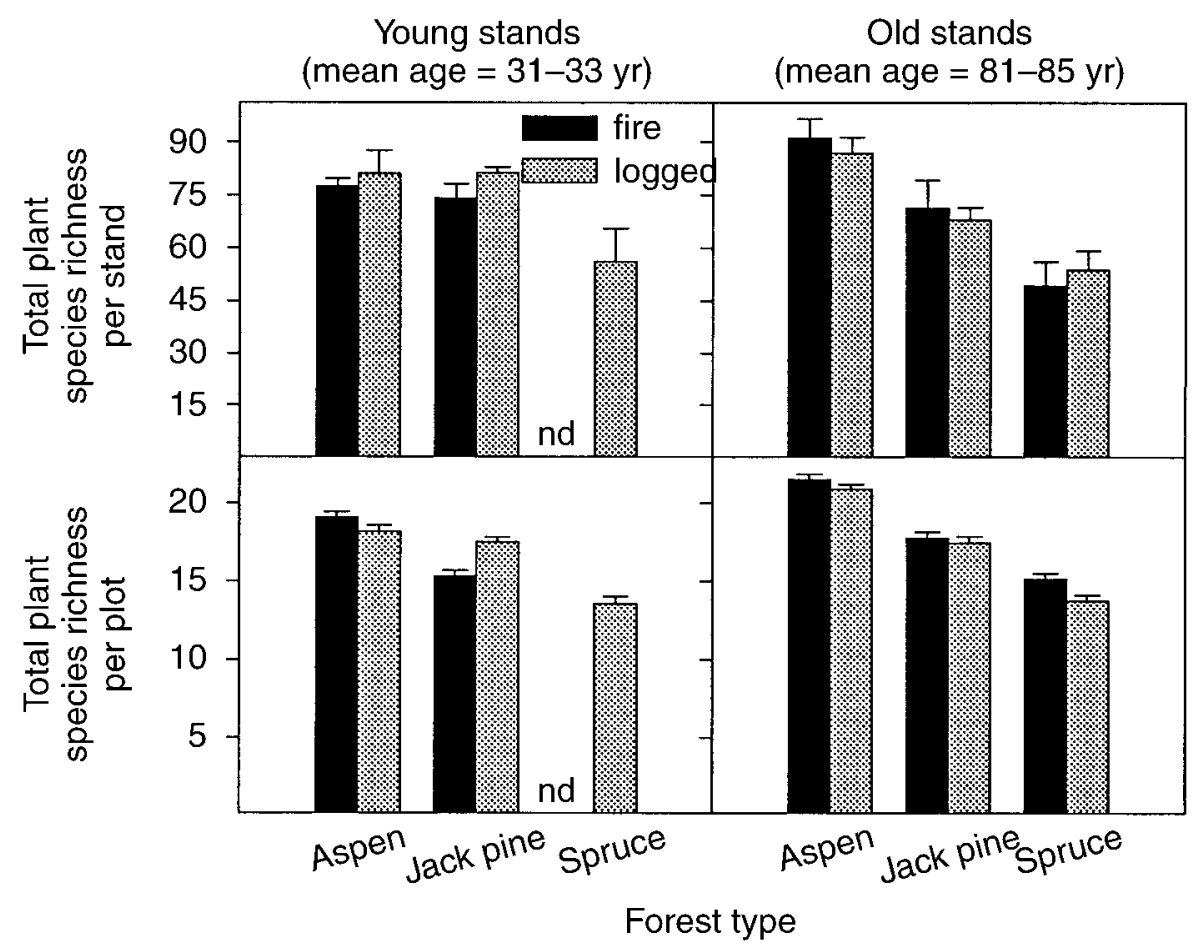

FIG. 4. Effects of disturbance type (fire vs. logging) and forest type on the total number (vascular plants plus bryophytes) of plant species per plot (mean +1 SE; mean of $251.8-\mathrm{m}^{2}$ plots) and per stand (aggregate of 25 plots). The "nd" indicates that no data are available (see Fig. 1). All variables differed significantly among forest types. Otherwise as in Fig. 3. 
TABLE 5. Diversity indices for vascular plant species for 80 forest stands in northeastern Minnesota, USA.

\begin{tabular}{lllccc}
\hline \hline Stand type & Age class & Origin & $\begin{array}{c}\text { Mean } \\
\text { evenness }\end{array}$ & $\begin{array}{c}\text { Mean } \\
\text { Shannon }\end{array}$ & $\begin{array}{c}\text { Mean } \\
\text { Whittaker's } \beta\end{array}$ \\
\hline Aspen & old & postfire & $0.89(0.01)$ & $3.54(0.07)$ & $2.6(0.2)$ \\
Aspen & old & postlogged & $0.89(0.01)$ & $3.47(0.07)$ & $2.7(0.2)$ \\
Aspen & young & postfire & $0.89(0.01)$ & $3.28(0.08)$ & $2.4(0.1)$ \\
Aspen & young & postlogged & $0.90(0.01)$ & $3.60(0.08)$ & $3.0(0.2)$ \\
Black spruce & old & postfire & $0.88(0.01)$ & $2.62(0.10)$ & $1.6(0.4)$ \\
Black spruce & old & postlogged & $0.88(0.01)$ & $2.69(0.10)$ & $2.2(0.3)$ \\
Black spruce & young & postlogged & $0.86(0.01)$ & $2.81(0.22)$ & $2.5(0.6)$ \\
Jack pine & old & postfire & $0.88(0.01)$ & $3.30(0.08)$ & $3.0(0.3)$ \\
Jack pine & old & postlogged & $0.89(0.01)$ & $3.35(0.08)$ & $2.7(0.3)$ \\
Jack pine & young & postfire & $0.88(0.01)$ & $3.27(0.08)$ & $3.6(0.3)$ \\
Jack pine & young & postlogged & $0.89(0.01)$ & $3.47(0.07)$ & $3.0(0.2)$ \\
\hline
\end{tabular}

Note: Data are means (with 1 SE in parentheses) for evenness, Shannon's diversity index, and Whittaker's $\beta$-diversity index (all at a stand scale).

differences among forest types. In ordination of either vascular plant or bryophyte species composition, stands established following logging do not segregate from those established following fire (Fig. 5), and all stands array themselves in a continuum. Aspen and spruce stands occupy distinctly different zones, with jack pine communities occupying the intermediate ordination space, overlapping more with aspen than spruce.

MRPP analyses showed that all three forest types differed significantly from each other in composition and young stands differed from older stands (Table 6). Stands established postfire did not differ from those established postlogging, either tested by forest type or for all stands together. However, for young stands, differences between postfire and postlogging stands were close to significant $(P=0.11)$ while those for older stands were not $(P=0.55)$, consistent with other mea- sures such as richness and Shannon's diversity index that suggest a systematic difference among young but not old stands in composition and diversity as a function of disturbance type prior to stand initiation.

Abundant, common, and rare species were present just as frequently following logging as fire (Table 7). For example, the rarest $20 \%$ of all vascular plant species (total of 41 ) were found on average in $1.1 \%$ of all postfire stands and $1.5 \%$ of all postlogged stands (Table 7). The most common $20 \%$ of all vascular plant species were found in a mean of $64.6 \%$ of all postfire stands and $62.7 \%$ of all postlogged stands (Table 7). These patterns were similar to those for bryophytes species (Table 7).

Even examined individually, the vast majority of species, whether rare or abundant, tended to be found on average in roughly proportional numbers of postfire and postlogging stands (Table 8). For the most common

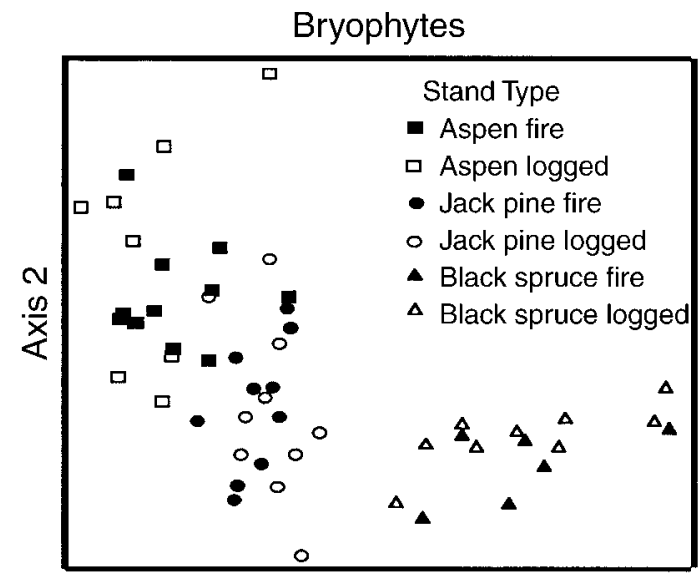

Axis 1

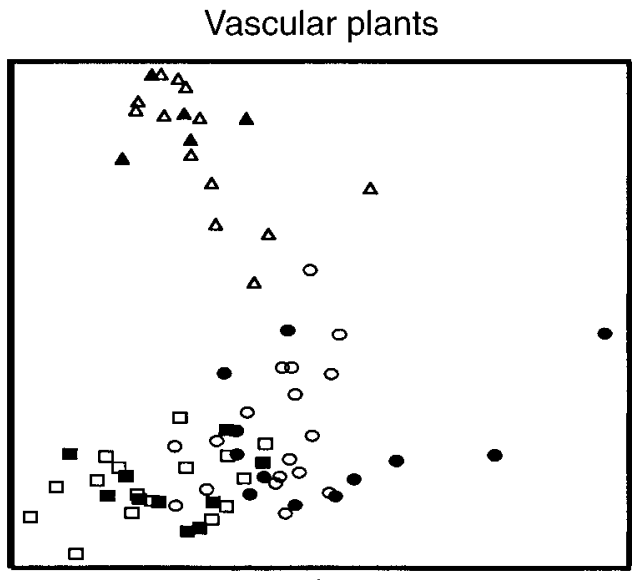

Axis 1

FIG. 5. Ordination (nonmetric multidimensional scaling) of community composition for bryophytes and vascular plants for stands of three types established following either logging or wildfire (pooling across stand age). Stands located nearest one another on each graph have the most similar species assemblages, while those located farthest away are the least similar. The position with respect to the axes is meaningless in comparing the two panels. Both vascular plants and bryophytes segregate into different communities based on forest type (note distance of aspen communities from spruce communities), but not based on disturbance type (compare positions of postlogged and postfire stands). 
TABLE 6. Results of multiple response permutation procedures to test for differences in vascular plant species composition among stand contrasts.

\begin{tabular}{llclcrl}
\hline \hline \multirow{2}{c}{ Group } & Subgroup & $\begin{array}{c}\text { Mean } \\
\text { distance }\end{array}$ & Subgroup & $\begin{array}{c}\text { Mean } \\
\text { distance }\end{array}$ & $\begin{array}{c}\text { Test } \\
\text { statistic }\end{array}$ & $P$ \\
\hline All stands & postfire & 0.735 & postlogging & 0.769 & -0.9 & 0.15 \\
& young & 0.775 & old & 0.710 & -3.2 & $\mathbf{0 . 0 1}$ \\
& aspen & 0.687 & jack pine & 0.600 & -10.7 & $\mathbf{0 . 0 0 0 1}$ \\
& jack pine & 0.600 & black spruce & 0.588 & -24.2 & $\mathbf{0 . 0 0 0 1}$ \\
& aspen & 0.687 & black spruce & 0.588 & -30.1 & $\mathbf{0 . 0 0 0 1}$ \\
Young stands & postfire & 0.731 & postlogging & 0.663 & -1.2 & 0.11 \\
Old stands & postfire & 0.761 & postlogging & 0.792 & 0.4 & 0.55 \\
Aspen stands & postfire & 0.583 & postlogging & 0.620 & 0.5 & 0.64 \\
& young & 0.589 & old & 0.581 & -3.2 & $\mathbf{0 . 0 0 9}$ \\
Jack pine stands & postfire & 0.683 & postlogging & 0.682 & -0.8 & 0.18 \\
& young & 0.640 & old & 0.681 & -4.3 & $\mathbf{0 . 0 0 3}$ \\
Black spruce stands & postfire & 0.606 & postlogging & 0.592 & 0.9 & 0.83 \\
& young & 0.603 & old & 0.560 & 0.8 & 0.78 \\
\hline
\end{tabular}

Notes: The test statistic describes the separation between the groups and is defined as the difference between the observed delta (the mean within-group distance) and the expected delta (calculated to represent the mean delta for all possible partitions of the data). The $P$ value expresses the likelihood of getting a delta as extreme or more extreme than the observed delta, given the distribution of possible deltas. Boldface $P$ values indicate $P<0.10$.

vascular plant species (found in more than one-third of all stands of either origin), there was little tendency for species to be substantially more common on either postlogged or postfire stands and no tendency for a species to be absent on one type or the other (Table 8). For example, the five common species (or species groups) with the greatest tendency to occur postlogging rather than postfire (Carex spp., Smilacina trifolium, Gaultheria hispidula, Ledum groenlandicum, and Aster spp.) were still common postfire (percentage of stands present; $96 \%$ vs. $77 \%, 44 \%$ vs. $26 \%, 44 \%$ vs. $29 \%$, $54 \%$ vs. $40 \%$, and $41 \%$ vs. $29 \%$, respectively). Similarly, the five common species with the greatest tendency to occur postfire rather than postlogging ( $L y$ copodium obscurum, Cornus canadensis, Aralia nudicaulis, Fragaria spp., and Coptis groenlandica) were still common postlogging ( $71 \%$ vs. $46 \%, 89 \%$ vs. $72 \%$, $83 \%$ vs. $67 \%, 54 \%$ vs. $39 \%$, and $52 \%$ vs. $37 \%$, respectively). Of all 241 vascular plant species observed, only one (Lycopodium obscorum) was significantly ( $P$ $<0.05)$ more common postfire than postlogging and one group (Carex spp.) was significantly more common postlogging than postfire. Individual bryophytes spe- cies also tended to occur in roughly proportional numbers of postfire and postlogging stands (Table 8 ).

\section{Multiple-stand species richness}

We also assessed the potential role of disturbance and forest type in affecting multiple-stand (i.e., landscape-scale) species richness. To make these comparisons we randomly selected 13 stands from the total number of stands within several alternative groupings (e.g., postfire vs. postlogging or aspen vs. jack pine vs. spruce) and counted the total number of vascular plant species present. We then repeated the entire process at least eight times. We used 13 stands because it was among the lowest number possible to use for most groupings of interest and yet represents a reasonable number of stands (with more than twice as many species present as the mean per stand and roughly half as many as found in all 80 stands). Overall results showed patterns similar to those at a stand scale. A slightly greater number (mean $\pm 1 \mathrm{SE}$ ) of vascular plant species was encountered in groups of 13 logged stands (all forest types; $138 \pm 3$ species) than of 13 postfire stands $(130 \pm 2$ species $)$, with a similar contrast within each

TABLE 7. Mean proportional occurrence (percentage of stands; with 1 SE in parentheses) of rare, common, and abundant vascular herbaceous species and bryophyte species on postlogging and postfire stands (pooled across forest types and age classes).

\begin{tabular}{|c|c|c|c|c|}
\hline \multirow{2}{*}{$\begin{array}{l}\text { Relative } \\
\text { abundance } \\
\text { ranking }\end{array}$} & \multicolumn{2}{|c|}{ Herbaceous species } & \multicolumn{2}{|c|}{ Bryophyte species } \\
\hline & Fire & Logged & Fire & Logged \\
\hline $1-20$ & $64.6(2.3)$ & $62.7(2.4)$ & $66.6(4.0)$ & $61.5(3.6)$ \\
\hline $21-40$ & $23.9(1.3)$ & $27.7(1.2)$ & $24.9(1.6)$ & $22.5(1.8)$ \\
\hline $41-60$ & $8.7(0.5)$ & $9.9(0.6)$ & $7.7(0.7)$ & $6.9(0.7)$ \\
\hline $61-80$ & $3.6(0.3)$ & $4.3(0.4)$ & $3.8(0.8)$ & $3.4(0.7)$ \\
\hline $81-100$ & $1.1(0.2)$ & $1.5(0.2)$ & $1.9(0.3)$ & $1.8(0.3)$ \\
\hline
\end{tabular}

Note: Relative abundance ranking based on percentage of occurrence, by quintiles, with $1-$ 20 being most abundant and $81-100$ being rarest. 
TABLE 8. List of the most common vascular plant and bryophyte species (found in at least one-third of either fire or logging origin stands) and their proportional occurrence (percentage of stands) on postlogging and postfire stands (pooled across forest types and age classes).

\begin{tabular}{|c|c|c|c|c|c|}
\hline \multicolumn{3}{|c|}{ Vascular plant species } & \multicolumn{3}{|l|}{ Bryophyte species } \\
\hline Species name & $\begin{array}{l}\text { Post- } \\
\text { fire }\end{array}$ & $\begin{array}{c}\text { Post- } \\
\text { logging }\end{array}$ & Species name & $\begin{array}{l}\text { Post- } \\
\text { fire }\end{array}$ & $\begin{array}{c}\text { Post- } \\
\text { logging }\end{array}$ \\
\hline Lycopodium obscurum & 71.4 & 45.7 & Polytrichum commune & 44.8 & 23.1 \\
\hline Cornus canadensis & 88.6 & 71.7 & Sphagnum angustifolium & 55.2 & 38.5 \\
\hline Aralia nudicaulis & 82.9 & 67.4 & Sphagnum magellanicum & 48.3 & 34.6 \\
\hline Fragaria spp. & 54.3 & 39.1 & Dicranum montanum & 34.5 & 26.9 \\
\hline Coptis groenlandica & 51.4 & 37.0 & Sphagnum russowii & 37.9 & 30.8 \\
\hline Acer spicatum & 48.6 & 37.0 & Hypnum pallescens & 96.6 & 92.3 \\
\hline Corylus cormuta & 82.9 & 71.7 & Mnium spinulosum & 34.5 & 30.8 \\
\hline Solidago spp. & 45.7 & 34.8 & Polytrichum strictum & 37.9 & 34.6 \\
\hline Melampyrum lineare & 51.4 & 41.3 & Sphagnum capillifolium & 37.9 & 34.6 \\
\hline Apocynum androsaemifolium & 54.3 & 45.7 & Dicranum ontariense & 75.9 & 73.1 \\
\hline Pteridium aquilunum & 62.9 & 54.3 & Brachythecium oedipodium & 82.8 & 80.8 \\
\hline Diervilla lonicera & 80.0 & 71.7 & Aulacomnium palustre & 51.7 & 50.0 \\
\hline Lonicera canadensis & 51.4 & 43.5 & Brachythecium salebrosum & 51.7 & 50.0 \\
\hline Betula papyrifera & 65.7 & 58.7 & Ptilium crista-castrensis & 69.0 & 69.2 \\
\hline Vaccinium angustifo & 91.4 & 84.8 & Campylium hispidulum & 41.4 & 42.3 \\
\hline Lathyrus venosus & 34.3 & 28.3 & Plagiothecium laetum & 41.4 & 42.3 \\
\hline Acer rubrum & 74.3 & 69.6 & Tetraphis pellucida & 51.7 & 53.8 \\
\hline Amelanchier spp. & 82.9 & 78.3 & Sanionia uncinata & 86.2 & 88.5 \\
\hline Galium triflorum & 54.3 & 50.0 & Callicladium haldanianum & 93.1 & 96.2 \\
\hline Populus tremuloides & 68.6 & 65.2 & Ptilidium pulcherrimum & 93.1 & 96.2 \\
\hline Oryzopsis asperifolia & 65.7 & 63.0 & Dicranum scoparium & 62.1 & 65.4 \\
\hline Gaultheria procumbens & 37.1 & 34.8 & Bryohaplocladium microphyllum & 37.9 & 42.3 \\
\hline Lycopodium annotinum & 37.1 & 34.8 & Brachythecium erythrorrhizon & 69.0 & 76.9 \\
\hline Lonicera hirsuta & 45.7 & 43.5 & Dicranum polysetum & 86.2 & 96.2 \\
\hline Vaccinium myrtilloides & 71.4 & 69.6 & Pohlia nutans & 58.6 & 69.2 \\
\hline Maianthemum canadense & 85.7 & 84.8 & Pylaisiella polyantha & 31.0 & 42.3 \\
\hline Picea glauca & 40.0 & 39.1 & Plagiomnium cuspidatum & 34.5 & 46.2 \\
\hline Rubus strigosus & 57.1 & 56.5 & Platygyrium repens & 41.4 & 53.8 \\
\hline Aster macrophyllus & 77.1 & 78.3 & Polytrichum juniperinum & 51.7 & 65.4 \\
\hline Rubus pubescens & 74.3 & 76.1 & Pleurozium schreberi & 86.2 & 100.0 \\
\hline Viola spp. & 74.3 & 76.1 & Eurhynchium pulchellum & 20.7 & 34.6 \\
\hline Anemone quinquefolia & 62.9 & 65.2 & Brachythecium velutinum & 55.2 & 69.2 \\
\hline Prunus virginiana & 34.3 & 37.0 & Hedwigia ciliata var. ciliata & 24.1 & 38.5 \\
\hline Rosa acicularis & 60.0 & 63.0 & Brachythecium reflexum & 41.4 & 57.7 \\
\hline Lycopodium clavatum & 40.0 & 43.5 & Jamesoniella autumnalis & 44.8 & 61.5 \\
\hline Clintonia borealis & 71.4 & 76.1 & Thuidium recognitum & 20.7 & 38.5 \\
\hline Other grass species & 80.0 & 84.8 & Dicranum flagellare & 79.3 & 100.0 \\
\hline Salix spp. & 51.4 & 56.5 & Lophocolea heterophylla & 58.6 & 84.6 \\
\hline Trientalis borealis & 77.1 & 82.6 & & & \\
\hline Alnus rugosa & 31.4 & 37.0 & & & \\
\hline Picea mariana & 54.3 & 63.0 & & & \\
\hline Linnaea borealis & 48.6 & 58.7 & & & \\
\hline Streptopus roseus & 48.6 & 58.7 & & & \\
\hline Abies balsamea & 65.7 & 76.1 & & & \\
\hline Alnus crispa & 37.1 & 47.8 & & & \\
\hline Aster spp. & 28.6 & 41.3 & & & \\
\hline Ledum groenlandicum & 40.0 & 54.3 & & & \\
\hline Gaultheria hispidula & 28.6 & 43.5 & & & \\
\hline Smilacina trifolia & 25.7 & 43.5 & & & \\
\hline Carex spp. & $\mathbf{7 7 . 1}$ & 95.7 & & & \\
\hline
\end{tabular}

Notes: Species are listed, first to last, from those with the largest habitat preference for postfire to those with largest habitat preference for postlogging (based on absolute difference in percentage of occurrence). Species and associated data are shown in bold when differences between postfire and postlogged stands were significant $(P<0.05)$.

forest type. Jack pine (123 \pm 3 species $)$ and especially black spruce stands $(84 \pm 1$ species $)$ contained fewer vascular plant species per 13 stands than aspen (132 \pm 3 species).

\section{Biomass, productivity, and $N$ cycling}

Biomass and basal area were similar for fire vs. logging origin stands within forest type and age class com- binations, and were greatest in aspen and least in spruce stands (Table 1). There were no effects of stand origin or stand age on litter, stem wood, or total aboveground production (Fig. 6, Tables 9 and 10), but these measures were all significantly greater in aspen than jack pine and least in spruce stands.

Litter nitrogen concentrations and total litter $\mathrm{N}$ were greater in aspen stands than in either conifer type (Tables 


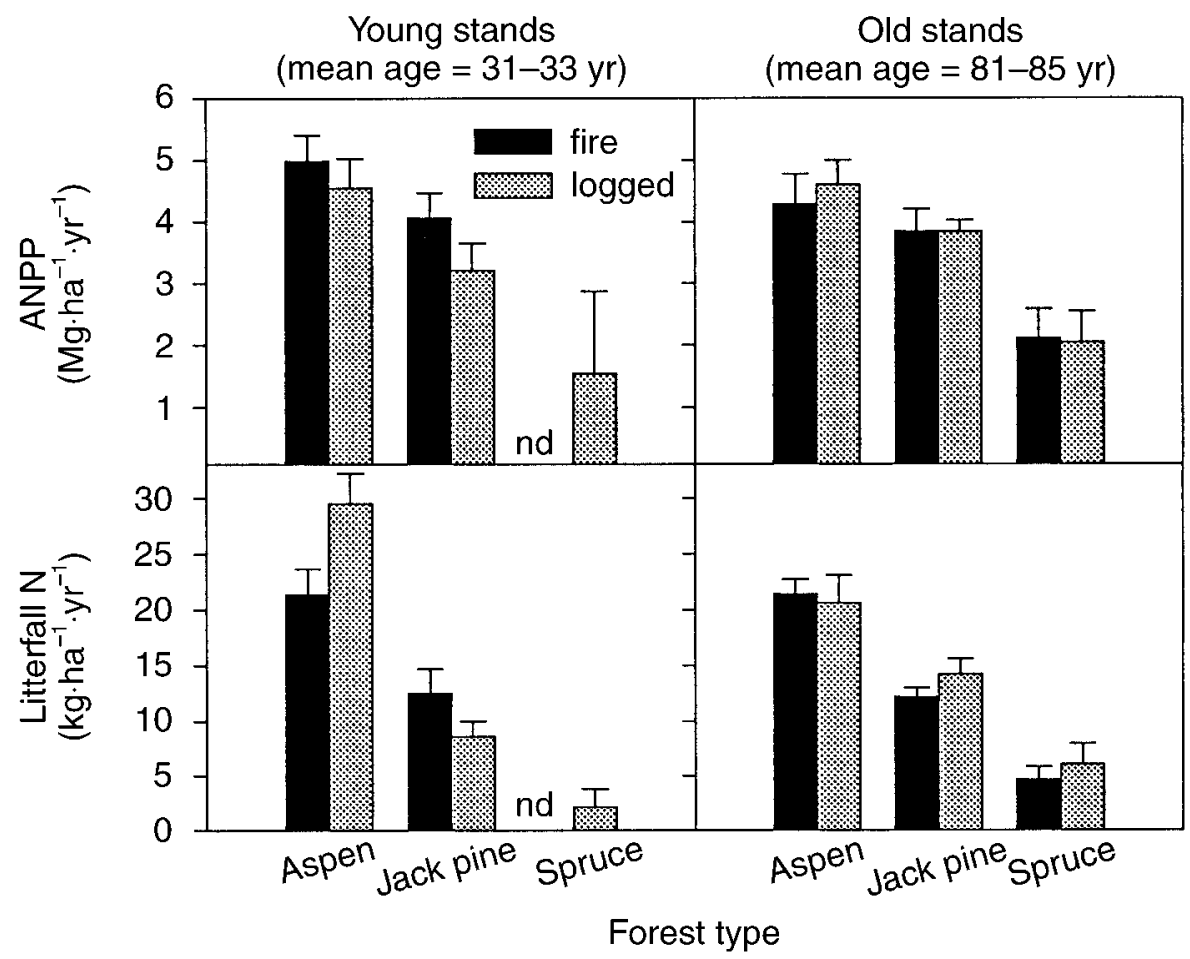

FIG. 6. The mean annual aboveground net primary production (ANPP) and litterfall nitrogen per stand (mean $+1 \mathrm{SE}$ ). The "nd" indicates that no data are available (see Fig. 1). All 80 stands were used in this analysis.

9 and 10; Fig. 6). Aspen and jack pine stands showed opposite $(P<0.002)$ stand age and origin patterns for litter percentage $\mathrm{N}$ and total litter $\mathrm{N}$. Older stands had lower total $\mathrm{N}$ and percentage of $\mathrm{N}$ in litter than younger stands for aspen, especially postlogging, with the reverse true for jack pine. Midsummer soil net $\mathrm{N}$ mineralization rates were not different postfire (mean $\pm 1 \mathrm{SE}$, among all types, $\left.0.27 \pm 0.07 \mathrm{~kg} \cdot \mathrm{ha}^{-1} \cdot \mathrm{d}^{-1}\right)$ than postlogging $(0.27 \pm 0.08)$, and the mean of these rates were higher in aspen $(0.35 \pm 0.08)$, intermediate in jack pine $(0.29$ $\pm 0.09)$, and least in spruce $(0.12 \pm 0.10)$, although these differences were not statistically significant.
Soil and litter attributes differed slightly between postfire vs. postlogging origin or between stand ages (Tables 2 and 3). There was a tendency for percentage soil carbon to be greater postfire than postlogging in aspen stands but the opposite pattern was found in jack pine stands. Black spruce stands were more acidic on average than either jack pine or aspen stands. Forest floor litter tended to have a greater $\mathrm{Mg}, \mathrm{Ca}, \mathrm{K}$, and $\mathrm{P}$ concentration in aspen than in jack pine stands, with spruce lowest (Table 3), but there were no consistent differences in soil extractable $\mathrm{Mg}, \mathrm{Ca}$, or $\mathrm{K}$ between aspen and jack pine stands.

TABLE 9. Productivity and litterfall nitrogen concentration data (with 1 SE in parentheses) for 80 forest stands in northeastern Minnesota, USA.

\begin{tabular}{|c|c|c|c|c|c|}
\hline Stand type & Age class & Origin & 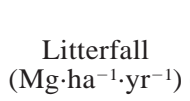 & $\begin{array}{c}\text { Stem wood } \\
\text { production } \\
\left(\mathrm{Mg} \cdot \mathrm{ha}^{-1} \cdot \mathrm{yr}^{-1}\right)\end{array}$ & Litter N (\%) \\
\hline Aspen & old & postfire & $2.6(0.3)$ & $1.7(0.3)$ & $0.74(0.07)$ \\
\hline Aspen & old & postlogged & $2.9(0.2)$ & $1.7(0.3)$ & $0.68(0.07)$ \\
\hline Aspen & young & postfire & $2.5(0.2)$ & $2.5(0.3)$ & $0.87(0.07)$ \\
\hline Aspen & young & postlogged & $2.9(0.3)$ & $1.7(0.4)$ & $1.00(0.06)$ \\
\hline Black spruce & old & postfire & $1.0(0.2)$ & $1.1(0.3)$ & $0.41(0.05)$ \\
\hline Black spruce & old & postlogged & $1.1(0.3)$ & $0.9(0.2)$ & $0.51(0.05)$ \\
\hline Black spruce & young & postlogged & $0.5(0.4)$ & $1.1(1.0)$ & $0.49(0.09)$ \\
\hline Jack pine & old & postfire & $2.5(0.2)$ & $1.4(0.2)$ & $0.58(0.07)$ \\
\hline Jack pine & old & postlogged & $2.8(0.3)$ & $1.1(0.2)$ & $0.60(0.07)$ \\
\hline Jack pine & young & postfire & $2.4(0.4)$ & $1.7(0.3)$ & $0.53(0.07)$ \\
\hline Jack pine & young & postlogged & $2.0(0.2)$ & $1.4(0.3)$ & $0.47(0.06)$ \\
\hline
\end{tabular}


TABLE 10. Analyses of variance summary for productivity and litterfall N cycling.

\begin{tabular}{|c|c|c|c|c|c|c|c|c|c|}
\hline \multirow[b]{2}{*}{ Parameter } & \multicolumn{4}{|c|}{ Effects of forest type and disturbance } & \multicolumn{4}{|c|}{ Effects of forest type and stand age } & \multirow[b]{2}{*}{$R^{2}$} \\
\hline & $R^{2}$ & $\begin{array}{l}\text { Forest } \\
\text { type }\end{array}$ & Origin & $\begin{array}{c}\text { Forest } \\
\text { type } \\
\times \text { origin }\end{array}$ & $R^{2}$ & $\begin{array}{l}\text { Forest } \\
\text { type }\end{array}$ & $\begin{array}{l}\text { Stand } \\
\text { age }\end{array}$ & $\begin{array}{l}\text { Forest } \\
\text { type } \\
\times \text { age }\end{array}$ & \\
\hline$\overline{\mathrm{ANPP}}$ & 0.47 & $<\mathbf{0 . 0 0 0 1}$ & 0.83 & 0.90 & 0.43 & $<\mathbf{0 . 0 0 0 1}$ & 0.38 & 0.82 & 0.20 \\
\hline Litterfall production & 0.53 & $<\mathbf{0 . 0 0 0 1}$ & 0.32 & 0.95 & 0.53 & $<\mathbf{0 . 0 0 0 1}$ & 0.06 & 0.38 & 0.18 \\
\hline Stem wood production & 0.18 & 0.04 & 0.44 & 0.89 & 0.12 & 0.16 & 0.61 & 0.94 & 0.19 \\
\hline Litterfall $\mathrm{N}$ & 0.62 & $<\mathbf{0 . 0 0 0 1}$ & 0.35 & 0.97 & 0.75 & $<\mathbf{0 . 0 0 0 1}$ & 0.64 & 0.008 & 0.56 \\
\hline Litter N (\%) & 0.39 & 0.0001 & 0.60 & 0.33 & 0.63 & 0.0001 & 0.28 & 0.002 & 0.52 \\
\hline
\end{tabular}

Notes: ANOVA results are shown for aboveground net primary production (ANPP, $\mathrm{Mg} \cdot \mathrm{ha}^{-1} \cdot \mathrm{yr}^{-1}$ ), litterfall production $\left(\mathrm{Mg} \cdot \mathrm{ha}^{-1} \cdot \mathrm{yr}^{-1}\right)$, stem wood production $\left(\mathrm{Mg} \cdot \mathrm{ha}^{-1} \cdot \mathrm{yr}^{-1}\right)$, litterfall $\mathrm{N}$ production $\left(\mathrm{kg} \cdot \mathrm{ha}^{-1} \cdot \mathrm{yr}^{-1}\right)$, and litter $\% \mathrm{~N}$ in relation to: (left) forest type and disturbance (mode of stand origin), for old stands of three types (aspen, jack pine, and black spruce) in two disturbance classes (postlogging and postfire); (center) forest type and stand age, for logged stands of all three types in two age classes (young and old); (right) forest type, stand age (young vs. old), and disturbance (mode of stand origin), for stands of two types (aspen and jack pine). $R^{2}$ values shown are for the whole model. $P$ values are shown for main effects and interactions (boldface when $P<0.10$ ).

\section{Discussion}

Sustainability of diversity, fertility, and productivity at the stand scale were not adversely affected by 20 th century logging, using naturally disturbed postfire stands of similar type and age as the standard of comparison. This supports, at least in part, the NDM of forest management idea of replacing wildfire with logging as the mode of disturbance and stand initiation. However, several issues must be considered in interpreting these results. In particular, it must be recognized that our study investigated understory and canopy tree species responses to logging and natural fire disturbance events, controlling for postdisturbance stand age and stand type. Whether and how NDM, if implemented in Minnesota, would affect forest characteristics such as forest type composition or stand age structure at the landscape scale is still unclear. If these characteristics do change, what are the implications? In the following discussion, we first discuss controls on diversity, composition, fertility and productivity in relation to disturbance type, forest type and stand age, and then address these important issues.

Influence of fire, logging, and stand age on diversity and productivity

Collectively, these data suggest that previously logged boreal forests are generally similar at the stand scale in terms of composition, species diversity, and productivity compared to similar forest types originated after wildfire. The only marked difference between stand origin classes was noted for vascular plants, where young stands of both the jack pine and aspen type had greater species richness and Shannon's diversity index and different composition postlogging than postfire. These differences were driven primarily by differences in herbaceous species composition. Could the relatively limited differences we observed postfire vs. postlogging be due to their relative similarity of disturbance severity?

Using a conceptual definition of disturbance severity (cf. Oliver and Larson 1990, Frelich and Reich 1999), crown fire in the boreal forest is an equal or more severe disturbance than logging. While crown fires and logging both kill overstory individuals, logging probably kills fewer understory individuals. Both disturbances are sufficiently patchy that there typically remain sufficient numbers of minimally disturbed microsites with either living plants or propagules to assure reinvasion over time (Ahlgren 1960, Heinselman 1973, Johnson 1992, Turner et al. 1997). Timber removal results in a loss of carbon and nutrients from the ecosystem, whereas wildfire can burn the litter layer, reduce soil organic matter, and remove nutrients (Ahlgren 1960, Heinselman 1973, Johnson 1992, Turner et al. 1997), which collectively could reduce rates of nutrient cycling and perhaps offset potential stimulation of nitrogen mineralization rates by wildfire (Zackrisson et al. 1996, Wardle et al. 1997). Net primary production, litterfall nitrogen cycling and nitrogen mineralization rates were similar following fire and logging. Thus, disruption of nutrient cycling, propagule availability, and soil physical integrity that accompany logging also occur during severe crown fires (Zackrisson et al. 1996, Wardle et al. 1997), although not identically. Natural disturbance in this case is not gentle. The NDM may be feasible theoretically given that both logging and fire are relatively severe disturbances, although forest type composition over time will likely vary depending on which disturbance is dominant and the rate of such disturbance.

Our study results can be compared with prior studies that fall largely into two categories: those that contrasted younger postlogging stands with older naturally disturbed stands, and those that contrasted very young stands following logging vs. wildfire. Several prior studies compared younger aged postlogging stands with older mature or old-growth stands established following natural disturbances. They found significant differences among those groups in diversity and composition (Schoonmaker and McKee 1988, Duffy and 
TABle 10. Extended.

\begin{tabular}{cccl}
\hline \hline \multicolumn{3}{c}{ Effects of forest type, stand age, and disturbance } \\
\hline $\begin{array}{c}\text { Forest } \\
\text { type }\end{array}$ & Age & Origin & \multicolumn{1}{c}{ Interaction } \\
\hline $\mathbf{0 . 0 0 6}$ & 0.85 & 0.42 & none \\
$\mathbf{0 . 0 9}$ & 0.18 & 0.61 & none \\
$\mathbf{0 . 0 2}$ & 0.13 & 0.12 & none \\
$<\mathbf{0 . 0 0 0 1}$ & 0.66 & 0.24 & Forest type $\times$ age $(P=\mathbf{0 . 0 0 7})$, \\
$<\mathbf{0 . 0 0 0 1}$ & 0.17 & 0.80 & $\begin{array}{l}\text { Forest type } \times \text { origin }(\boldsymbol{P}=\mathbf{0 . 0 8}) \\
\text { Forest type } \times \text { age }(\boldsymbol{P}=\mathbf{0 . 0 0 2})\end{array}$ \\
\hline
\end{tabular}

Meier 1992, Halpern and Spies 1995), and also tended to find dynamic changes in composition and diversity over time as stands age. In the boreal forest, Brumelis and Carleton (1979) found differences in the understory vegetation comparing groups of logged stands (mean stand age of 2, 9, 29, and $36 \mathrm{yr}$ ) with mature spruce stands in Ontario, and Carleton and MacLellan (1994) found differences in the woody plant composition in comparing young postlogged stands (mean age $23 \mathrm{yr}$ ) with older postfire stands (mean age $90 \mathrm{yr}$ ) in Ontario. In all such studies, however, it is difficult to separate the differences in composition arising from stand age (or time since disturbance) from those due to the disturbance type. Nonetheless, if a landscape age structure becomes markedly younger as a result of logging practices, such studies provide good indication of changes in composition.

Several authors have shown differences in tree regeneration (e.g., Ahlgren 1976) or in vascular species composition (e.g., Nguyen-Xuan et al. 2000) in very young stands following logging vs. fire in southern boreal forests, but few differences in diversity. Nguyen-Xuan et al. (2000) found differences in understory composition in very young $(<5$-yr-old) and young $(10-$ 15-yr-old) stands in Quebec between postfire and postlogging stands that were related to differences (fire vs. logging) in severity of forest floor disturbance. Taken in concert with our finding of modest differences postlogging vs. postfire in 30-yr-old stands and no differences in older stands, this suggests that differences occur early on due to the different immediate effects of fire vs. logging but that these differences do not initiate alternative compositional pathways other than as driven by stand conversion to other dominant tree species (see Discussion: Implications of forest type compositional changes). Instead, regardless of the mode of disturbance, composition within a forest type tends to converge by roughly age 30 in most respects and more so in older stands. However, diversity and composition varied as a function of stand age in our study, with older stands being slightly more diverse in canopy trees and less diverse in herbaceous species than younger stands. Most studies find marked variation in composition and sometimes in diversity associated with variation in stage of stand development, regardless of prior disturbance agent (Schoonmaker and McKee 1988, DeGrandPre et al. 1993, Halpern and Spies 1995). Thus, the mixture of stand ages resulting from rates of disturbance by fire or logging is important (Bergeron and Harvey 1997).

\section{Differences among forest types}

The differences among forest types in diversity, composition, and productivity likely reflect both differences in habitat affinity-underlying gradients in soil physical properties, fertility, fire history, moisture, or understory light levels (Ohmann and Grigal 1985, Carleton 2000)_and feedback effects of the dominant tree species on resource availability and plant species composition (Pastor et al. 1984, Binkley 1995, Paré and Bergeron 1996, Wardle et al. 1997, Ste-Marie and Paré 1999). Aspen ANPP (mean of $4.6 \mathrm{Mg} \cdot \mathrm{ha}^{-1} \cdot \mathrm{yr}^{-1}$ ) was lower than in prior studies in central Canada (Gower et al. 1997) and Minnesota (Reich et al. 1997) but greater than prior estimates for northeastern Minnesota (Ohmann and Grigal 1985). Jack pine stands in this study (mean of $3.7 \mathrm{Mg} \cdot \mathrm{ha}^{-1} \cdot \mathrm{yr}^{-1}$ ) had somewhat greater ANPP than observed in central Canada (Gower et al. 1997) or estimated previously in northern Minnesota based on biomass accumulation over time (Ohmann and Grigal 1985). Spruce ANPP (mean of $2.0 \mathrm{Mg} \cdot \mathrm{ha}^{-1} \cdot \mathrm{yr}^{-1}$ ) was within the range observed previously in Minnesota (Grigal et al. 1985, Ohmann and Grigal 1985) and in North America (Gower et al. 1997).

Spruce stands, in contrast to jack pine and aspen, occupy wetter sites with organic soils and this likely has major influence on species composition, soil fertility, and productivity. Spruce also has lower leaf turnover rates, poorer litter quality, and low rates of leaf gas exchange (Reich et al. 1999), that are also likely to lead over time to dampening of $\mathrm{N}$ and $\mathrm{C}$ cycling rates (Ste-Marie and Paré 1999). These limitations on $\mathrm{C}$ and $\mathrm{N}$ cycling in turn will also likely influence species composition and productivity. Given that the jack pine and aspen stands in this study were found on similar soil-site types, it is likely that a substantial proportion of the differences in diversity and productivity between these forest types resulted from the influence of the dominant species. Aspen has greater leaf-level photosynthetic rates and higher tissue percentage of $\mathrm{N}$ than jack pine, and comparable leaf area index (Gower et al. 1997, Reich et al. 1999; P. Reich, unpublished data), likely leading to their greater ANPP. Aspen also has greater litterfall $\mathrm{N}$ and better litter quality (Table 8; e.g., a lower $\mathrm{C}: \mathrm{N}$ ratio) which should lead to greater $\mathrm{N}$ mineralization rates (Binkley 1995, Paré and Bergeron 1996, Reich et al. 1997, Ste-Marie and Paré 1999). Although mode of stand turnover left a minimal legacy on species diversity, composition, or productivity, there were consistent and significant differences in all three parameters among forest types of all ages. 


\section{Implications of forest type compositional changes}

Even if logging, having historically replaced wildfire in much of northern Minnesota and adjacent regions, does not appear to reduce plant diversity or markedly alter composition directly when standardizing by dominant canopy type and stand age, it has markedly shifted landscape composition by conversion in many sites of the dominant tree layer from conifer to aspen (Carleton and MacLellan 1994, Frelich and Reich 1995, Bergeron and Harvey 1997, Grigal and Bates 1997). Without logging or wildfire (i.e., with fire suppression in reserve areas) an opposite shift toward dominance by later successional conifers occurs (Grigal and Ohmann 1975, Kuusela 1992b, Frelich and Reich 1995, Bergeron 2000). Although in central Ontario a large fraction of lowland black spruce stands converted to aspen following logging (Carleton and MacLellan 1994), this is not as common in Minnesota, where widespread conversion to aspen has come from stands previously in pine, larch, and birch, as well as spruce (Friedman et al. 2001). Nonetheless, any regional conversion from spruce or pine to aspen would likely lead to greater vascular species diversity and productivity at the stand scale, based on our current findings, since differences in diversity, nutrient cycling, and productivity among forest types are due in part to feedback effects of the dominant tree species on ecosystem processes (Pastor et al. 1984, Kuusela 1992a, b, Binkley 1995, Wardle et al. 1997). Moreover, if many postlogged aspen stands in our study had been conifer dominated previously, which is the most likely shift to have occurred in Minnesota, conversion to aspen rapidly increased their diversity and productivity, since on average the postlogging aspen stands had comparable or greater levels of both than postfire aspen stands.

Thus, any logging-induced shift toward greater dominance by aspen, as reported previously (Carleton and MacLellan 1994, Grigal and Bates 1997), may enhance stand-scale diversity, nutrient cycling, and productivity, but potentially reduce landscape-scale diversity if the regional shift is of significant magnitude. Carleton (2000) suggest that conversion to aspen leads to reduced beta diversity among stands, based on the much larger spread of natural postfire stands across ordination space than of the younger postlogged stands. However, the spread in ordination space of our postlogged aspen stands is not noticeably different than for postlogged aspen or other postlogged types. This pattern is distinct from that reported by Carleton (2000) and may reflect less site variation among upland sites in our study than in his, or confounding of stand age and disturbance history in the Ontario data.

\section{Implications of shifts in stand age structure}

Given that diversity and productivity are more directly sensitive to forest type and stand age than mode of disturbance, the combined effects of logging and fire suppression likely depend on how forest type and stand age are influenced by the spatial and temporal patterns of logging, the types of silvicultural systems employed, and the effectiveness and longevity of fire suppression (Heinselman 1973, Grigal and Ohmann 1975, Johnson 1992, Kuusela 1992b, Carleton and MacLellan 1994, Frelich and Reich 1995, Zackrisson et al. 1996, Bergeron and Harvey 1997, Grigal and Bates 1997, Turner et al. 1997). Although there may be no predictable stand age structure in a wildfire dominated landscape (Armstrong 1999), when compared to the observed multi-aged structure of the natural boreal forest landscape that occurs due to spatially and temporally irregular fire return intervals that range from 50 to 300 yr (Heinselman 1973, Johnson 1992), either logging or fire suppression can result in an unnatural stand age structure (Kuusela 1992b, Frelich and Reich 1995, Bergeron and Harvey 1997). Thus, a reduced amount of old growth accompanying shortened harvest rotations or an increased amount of old growth due to fire suppression are equally unnatural, and such landscapes would vary broadly and potentially in opposite directions in terms of diversity and productivity. Results of our study suggest NDM may be a feasible strategy; however, defining the optimal mix of composition and stand age structure desired for regional conservation and economic goals remains a difficult task.

\section{Conclusions}

Of course, not all issues involving southern boreal forest conservation fit into the framework provided by this study. Red and white pine do not regenerate well in disturbance regimes dominated by severe crown fires, fire suppression, or logging, and maintenance of these species in the southern boreal zone may require different disturbance regimes, such as periodic ground fires (Heinselman 1973, Frelich and Reich 1995). Northeastern Minnesota remains a heavily forested region and it is not clear how logging or fire suppression affect biodiversity and ecosystem functioning in regions where naturally forested landscapes are severely fragmented by conversion of substantial area to nonforested vegetation types. We should also recognize that comparisons of logging with fire in boreal forests might differ from comparisons of logging with natural disturbances in other biomes, especially where disturbances are less severe (e.g., windthrow), or where the stand age structure postlogging differs dramatically from that found under natural disturbance regimes.

In summary, the evidence developed here does not support the hypothesis that disturbance by logging in contrast to fire has limited diversity or productivity at the patch to stand scale in southern boreal forest stands. For diversity, this conclusion is similar to that of an independent companion study in Minnesota (P. Reich and colleagues, unpublished data) and that being reached in ongoing studies in western Canada (E. Johnson, personal comment). Although important, our find- 
ings should not be taken as a claim that logging and fire are equivalent, nor that replacement of fire by logging removes all threats to biodiversity and productivity. Some factors that influence biodiversity were not addressed (e.g., stand structure, such as the presence of logs and snags, or the full range of stand age classes). Moreover, typical forestry rotations currently in use do not match well with natural fire regimes, and will change the natural forest stand age distribution (Bergeron and Harvey 1997), which may not be stable in any case (Armstrong 1999). Economically viable forest rotations that maintain a more natural mix of stand ages are possible (Kuusela 1992b, Bergeron and Harvey 1997), but whether they are used is largely a sociopolitical question.

It is also important to view these results in a larger framework, such as that provided by a semiquantitative but comprehensive evaluation of all threats to imperiled species throughout the United States (Wilcove et al. 1998). That study suggested that a similar proportion of imperiled species were affected by logging and disruption of natural fire regimes, with two to three times as many species threatened by each of several other factors, including agriculture, land conversion for development, exotic species, outdoor recreation, or livestock grazing. Such comparisons should not be interpreted as minimizing the importance of logging or fire management as issues of concern for conservation of diversity and sustainability, but can provide a context for ranking the relative magnitude of the threats. Both logging and fire management do affect biodiversity and ecosystem functioning at a variety of scales through their influence on ecosystem composition, structure, and function.

\section{ACKNOWLEDGMENTS}

We thank L. Schmidt, R. Voldseth, J. Simonis, D. Bahauddin, and J. Bobrowski for their assistance and are most grateful to Jan Jannsen for sampling and identification of bryophyte species. Criticism by E. MacDonald and T. Carleton helped improve the manuscript. The work was supported by the Wilderness Research Foundation, the National Science Foundation (Award NSF/DEB-9524078), the National Council for Air and Stream Improvement, Inc., and the USDA McIntire-Stennis Program.

\section{Literature Cited}

Ahlgren, C. E. 1960. Some effects of fire on reproduction and growth of vegetation in northeastern Minnesota. Ecology 41:431-445.

Ahlgren, C. E. 1976. Regeneration of red pine and white pine following wildfire and logging in northeastern Minnesota. Journal of Forestry 74:135-140.

Alexeyev, V. A., and A. F. Tchmyr. 1997. The state of Russian boreal forests: impact of natural processes and human activity. Proceedings of XI World Forestry Congress 6:137144.

Armstrong, G. W. 1999. A stochastic characterisation of the natural disturbance regime of the boreal mixedwood forest with implications for sustainable forest management. Canadian Journal of Forest Research 29:424-433.

Bates, P. C., C. R. Blinn, and A. A. Alm. 1993. Harvesting impacts on quaking aspen regeneration in northern Min- nesota. Canadian Journal of Forest Research 23:24032412.

Bergeron, Y. 2000. Species and stand dynamics in the mixed woods of Quebec's southern boreal forest. Ecology 81: $1500-1516$

Bergeron, Y., and B. Harvey. 1997. Basing silviculture on natural ecosystem dynamics: an approach applied to the southern boreal mixed wood forest of Quebec. Forest Ecology and Management 92:235-242.

Binkley, D. 1995. The influence of tree species on forest soils: processes and patterns. Agronomy Society of New Zealand special publication number 10. Lincoln University Press, Canterbury, New Zealand.

Brumelis, G., and T. J. Carleton. 1989. The vegetation of post-logged black spruce lowlands in central Canada. II. Understory vegetation. Journal of Applied Ecology 26: 321-339.

Carleton, T. J. 2000. Vegetation responses to the managed forest landscape of central and northern Ontario. Pages 178-197 in: A. H. Perera, D. L. Euler, and I. Thompson, editors. Ecology of a managed terrestrial landscape. University of British Columbia Press, Vancouver, British Columbia, Canada.

Carleton, T. J., and P. MacLellan. 1994. Woody vegetation responses to fire versus clear-cutting logging: a comparative survey in the central Canadian boreal forest. Ecoscience 1:141-152.

De Grandprè, L., D. Gagnon, and Y. Bergeron. 1993. Changes in the understory of Canadian southern boreal forest after fire. Journal of Vegetation Science 4:803-810.

Duffy, D. C., and A. J. Meier. 1992. Do Appalachian herbaceous understories ever recover from clearcutting? Conservation Biology 6:196-201.

Dufrêne, M., and P. Legendre. 1997. Species assemblages and indicator species: the need for a flexible asymmetrical approach. Ecological Monographs 67:345-366.

Frelich, L. E., and P. B. Reich. 1995. Spatial patterns and succession in a Minnesota southern-boreal forest. Ecological Monographs 65:325-346.

Frelich, L. E., and P. B. Reich. 1999. Neighborhood effects, disturbance severity, and community stability in forests. Ecosystems 2:151-166.

Friedman, S. K., P. B. Reich, and L. E. Frelich. 2001. Multiple scale composition and spatial distribution patterns of the northeastern Minnesota presettlement forest. Journal of Ecology, in press.

Gilliam, F. S., and M. R. Roberts. 1995. Plant diversity in managed forests. Ecological Applications 5:911-912.

Gower, S. T., J. G. Vogel, J. N. Norman, C. J. Kucharik, S. J. Steele, and T. K. Snow. 1997. Carbon distribution and aboveground net primary production in aspen, jack pine and black spruce stands in Saskatchewan and Manitoba, Canada. Journal of Geophysical Research 102:2902929041.

Grigal, D. F., and P. C. Bates. 1997. Assessing impacts of forest harvesting - the Minnesota experience. Biomass and Bioenergy 13:213-222.

Grigal, D. F., C. G. Buttleman, and L. K. Kernik. 1985. Biomass and productivity of the woody strata of forested bogs in northern Minnesota. Canadian Journal of Botany 63: 2416-2424.

Grigal, D. F., and P. S. Homann. 1994. Nitrogen mineralization, groundwater dynamics, and forest growth on a Minnesota outwash landscape. Biogeochemistry 27:171-185.

Grigal, D. F., and L. F. Ohmann. 1975. Classification, description, and dynamics of upland plant communities within a Minnesota Wilderness Area. Ecological Monographs 45:389-457.

Halpern, C. A., and T. A. Spies. 1995. Plant species diversity 
in natural and managed forests of the Pacific Northwest. Ecological Applications 5:913-934.

Hansen, A. J., T. A. Spies, F. J. Swanson, and J. L. Ohmann. 1991. Conserving biodiversity in managed forests. BioScience 41:382-392.

Heinselman, M. L. 1973. Fire in the virgin forests of the Boundary Waters Canoe Area, Minnesota. Quaternary Research 3:329-382.

Hunter, M. L. 1993. Natural fire regimes as spatial models for managing boreal forests. Biological Conservation 65: $115-120$.

Johnson, E. A. 1992. Fire and vegetation dynamics. Cambridge University Press, Cambridge, UK.

Kimmins, J. P. 1996. Importance of soil and role of ecosystem disturbance for sustained productivity of cool temperate and boreal forests. Soil Science Society of America Journal 60: $1643-1654$

Kuusela, K. 1992a. The boreal forests: an overview. Unasylva 43:3-13.

Kuusela, K. 1992b. Boreal forestry in Finland: a fire ecology without fire. Unasylva 43:22-25.

Meier, A. J., S. P. Bratton, and D. C. Duffy. 1995. Possible ecological mechanisms for loss of vernal-herb diversity in logged eastern deciduous forests. Ecological Applications 5:935-946.

Nguyen-Xuan, T., Y. Bergeron, D. Simard, J. W. Fyles, and D. Paré. 2000. The importance of forest floor disturbance in the early regeneration patterns of the boreal forest of western and central Quebec: a wildfire vs. logging comparison. Canadian Journal of Forest Research 30:13531364.

Noble, I. R., and R. O. Slatyer. 1980. The use of vital attributes to predict successional changes in plant communities subject to recurrent disturbances. Vegetatio 43:5-21.

Ohmann, L. F., and D. F. Grigal. 1985. Biomass distribution of unmanaged upland forests in Minnesota. Forest Ecology and Management 13:205-222.

Oliver, C. D., and B. C. Larson. 1990. Forest stand dynamics. McGraw Hill, New York, New York, USA.

Paré, D., and Y. Bergeron. 1996. Effect of colonizing tree species on soil nutrient availability in a clay soil of the boreal mixedwood. Canadian Journal of Forest Research 26:1022-1031.

Pastor, J., J. Aber, C. McClaugherty, and J. Melillo. 1984 Aboveground production and $\mathrm{N}$ and $\mathrm{P}$ cycling along a ni- trogen mineralization gradient on Blackhawk Island, Wisconsin. Ecology 65:256-568.

Reich, P. B., D. S. Ellsworth, M. B. Walters, J. Vose, C Gresham, J. Volin, and W. Bowman. 1999. Generality of leaf traits relationships: a test across six biomes. Ecology 80: $1955-1969$.

Reich, P. B., D. F. Grigal, J. D. Aber, and S. T. Gower. 1997. Nitrogen mineralization and productivity in 50 hardwood and conifer stands on diverse soils. Ecology 78:335-347.

Rowe, J. S. 1983. Concepts of fire effects on plant individuals and species. Pages 65-80 in R. W. Wein and D. A. MacLean, editors. The role of fire in northern circumpolar ecosystems. Wiley, New York, New York, USA.

Salwasser, H. 1990. Gaining perspective: forestry in the future. Journal of Forestry 88:32-38.

Schoonmaker, P., and A. McKee. 1988. Species composition and diversity during secondary succession of coniferous forests in the western Cascade Mountains of Oregon. Forest Science 34:960-979.

Sokal, R. R., and F. J. Rohlf. 1981. Biometry. W. H. Freeman and Company, New York, New York, USA.

Ste-Marie, C., and D. Paré. 1999. Soil, pH and N availability effects on net nitrification in the forest floors of a range of boreal forest stands. Soil Biology and Biochemistry 31: 579-1589.

Ter-Mikaelian, M. T., and M. D. Korzuhkin. 1997. Biomass equations for sixty-five North American tree species. Forest Ecology and Management 97:1-24.

Turner, M., W. Romme, R. Gardner, and W. Hargrove. 1997. Effects of fire size and pattern on early succession in Yellowstone National Park. Ecological Monographs 67:411433.

Wardle, D. A., O. Zackrisson, G. Hornberg, and C. Gallet. 1997. The influence of island area on ecosystem properties. Science 277:1296-1299.

Weber, M. G., and B. J. Stocks. 1998. Forest fires and sustainability in the boreal forests of Canada. Ambio 27:545550 .

Wilcove, D. S., D. Rothstein, J. Dubow, A. Phillips, and E. Losos. 1998. Quantifying threats to imperiled species in the United States. BioScience 48:607-615.

Zackrisson, O., M. C. Nilsson, and D. A. Wardle. 1996. Key ecological function of charcoal from wildfire in the boreal forest. Oikos 77:10-19.

Zak, D. R., and D. R. Grigal. 1991. Nitrogen cycling in upland and wetland ecosystems of east-central Minnesota. Oecologia 88:189-196. 